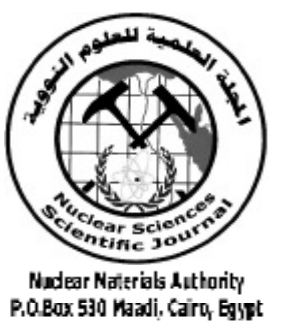

ISSN 2314-5609

Nuclear Sciences Scientific Journal

$6,35-53$

2017

http://www.ssnma.com

\title{
GEOLOGY AND GEOCHEMISTRY OF THE PERALUMINOUS GRANITES AT WADI UM ADDEBAA AREA, SOUTHEASTERN DESERT, EGYPT
}

\author{
FARRAGE M. KHALEAL \\ Nuclear Materials Authority, P. O. Box 530 El Maadi, Cairo, Egypt
}

\begin{abstract}
Wadi Um Addebaa area is located about $70 \mathrm{~km}$ Southwest of Marsa Alam City. The rocks exposed in this area include: ophiolitic metagabbro, ophiolitic mélange, peraluminous granite and post granite dykes and veins. The most common feature in the studied peraluminous granite is the presence of spessartine garnet aligned in monomineralic bands within its periphery ( $1 \mathrm{~m}$ thick) along the contact with
\end{abstract} the surrounding ophiolitic schists.

Petrographically, the peraluminous granite is mainly composed of sodic plagioclase (An 5-15), K- feldspar, quartz, muscovite and biotite. Sericite and chlorite are secondary minerals. Tourmaline, spessartine, zircon, allanite and opaques are accessory minerals.

Geochemical characteristics of the studied peraluminous granite indicate that this granite crystallized from relatively soda rich magma having peraluminous character, I-type, Syn-collision setting and has calc-alkaline affinity. It is emplaced at relatively shallower depth (water pressure 3-2 kb) in the crust and crystallized at temperature ranges from 800 to $760 \mathrm{C}^{\circ}$. It possesses high content of LILE (Rb, Y \& Zr) and has a moderate to high content of HFSE ( $\mathrm{Cu}, \mathrm{Zn}, \mathrm{Pb}, \mathrm{As}, \mathrm{Bi} \& \mathrm{~W})$. It constitutes an average $6.7 \mathrm{ppm}$ of Be content. Accordingly, it is believed that this granite is the source of beryl mineralization in Wadi El Gemal area.

Microprobe study of garnet revealed spessartine composition with core rich in $\mathrm{CaO}, \mathrm{MgO}, \mathrm{TiO}_{2}$ and $\mathrm{Y}_{2} \mathrm{O}_{3}$, while the rim is enriched in $\mathrm{FeO}, \mathrm{Al}_{2} \mathrm{O}_{3}$ and $\mathrm{SiO}_{2} . \mathrm{MnO}$ shows variable enrichments. The composition differs due to the variation in the ratio of $\mathrm{Fe}$ and $\mathrm{Mn}$. Whereas the $\mathrm{Mn}$ increases in the core more than the rim whereas Fe vice versa.

Radiometric study shows that, the peraluminous granite shows uranium and thorium contents with averages of $19 \mathrm{ppm}$ and 4.5 respectively, suggesting that it is fertile granite.

\section{INRODUCTION}

Wadi Um Addebaa is located about 70 $\mathrm{km}$ southwest of Marsa Alam City on the Red Sea coastal plane. It is a tributary of W. El Gemal. The studied Peraluminous granite is exposed in different locations in Wadi El Gemal area (W. Um Solimat, W. Sikait, W. Um El Kheran, W. Um Baanib and W. Um Addebaa). Among them, Peraluminous granite of W. Um Addebaa area comprises garnet crystals, in the periphery, organizing in clear bands

Peraluminous granites constitute a chemical subdivision of the granite family in which the whole rock molar ratio of alumina to lime, soda and potash $\left[\mathrm{Al}_{2} \mathrm{O}_{3} /\left(\mathrm{CaO}+\mathrm{Na}_{2} \mathrm{O}+\mathrm{K}_{2} \mathrm{O}\right)\right]$ abbreviated $\mathrm{A} / \mathrm{CNK}$ is greater than unity. Owing to their chemical and mineralogical similarities to metapelites, peraluminous granites are often considered to be genetically linked with these metasediments as source 
rocks and are thus referred to S-type granites. Peraluminous leucogranites are commonly associated with regionally metamorphosed and highly folded belts containing pelitic and quartzo-feldspathic sediments, for example the Tasman mobile belt of eastern Australia (Phillips, 1981).

Collisional leucogranites are characterized by peraluminous compositions and very low concentrations of $\mathrm{CaO}, \mathrm{MgO} \& \mathrm{FeO}$. In leucogranites, muscovite is a characteristic mineral, along with tourmaline or biotite. Almandine-spessartine garnet and minor sillimanite can also occur. Tourmaline and biotite are often exclusive of each other (Nabelek et al., 2001)

Syn-collision peraluminous granitic segregations are commonly associated with regionally metamorphosed terrains (Clemens and Wall; 1981); Debonet. al.,(1986); Inger and Harris (1993); Ibrahim et. al., (2001); and Salehet. al,. (2002). Numerous mechanisms have been proposed to explain the derivation of these segregations from the metamorphosed host rock, but partial melting of metapelites (Barbey, 1990) is still the most widely accepted model for the generation of these peraluminous leucogranites. Most of water required for this partial melting process may be derived from the breakdown of hydrous silicates inthese pelites such as muscovite and biotite minerals (Fyfe,1969).

Peraluminous granites with near-eutectic composition are common in collisional orogens, where they were produced by partial melting of deformed and metamorphosed accretionaly-wedge and ocean-floor sediments. Whilst there is a general agreement that leucogranites are anatectic of pelitic crustal sources. The heat sources for their production have remained controversial (Royden, 1993 and Thomposon and Connolly, 1995).

The pegmatitic granite is characterized by low contents of REEs $=(18-51 \mathrm{ppm})$. The particularly low $[\mathrm{La} / \mathrm{Yb}]_{\mathrm{n}}$ ratio in the garnetiferous granite is due to fractionation of
LREE-rich phases such as monazite, allanite and apatite (Mohamed and Hassanen (1997). Alternatively, the low $[\mathrm{La} / \mathrm{Yb}]_{\mathrm{n}}$ ratio in the garnetiferous granite is due to the light garnet abundance which appreciably accommodated the HREE (Gronet and Silver (1983)). Most of Egyptian granites are mainly metaluminous to slightly peraluminous, except rare ones (G. El-Sella and G. Ribdab), associated with U-mineralization (Ibrahim et. al., 2001).

In Egypt peraluminous leucogranites represent phases of late orogenic to an orogenic granite complex. They brought about $\mathrm{Mo}, \mathrm{Sn}$, $\mathrm{W}, \mathrm{U}$, and $\mathrm{Nb}$-Ta mineralization in the form of stock works or in the quartz veins within the granitic rocks (Hassan et al., 1984, Takla and Nowier1980).

The main target of the present work is to study the geology, geochemical characteristics and radiometry of the peraluminous granite embracing nice garnet crystals at Um Addebaa area, SED, Egypt.

\section{METHODS OF STUDY}

For petrographic and mineralogical study, nine polished thin sections were prepared at the University of New Brunzwick (UNB), Canada. Complete chemical analyses (major, trace and REE elements) for nine samples of the studied peraluminous granite were carried out by using X-ray Fluorescence spectrometer at Activation Laboratories (ACTLABS), Ontario, Canada. Backscattered electron images were collected by scanning electron microscope-energy dispersive spectrometry (BSE) (model JEOL 6400 SEM) at the Microscopy and Microanalyses Facility, University of New Brunswick (UNB), Fredericton, New Brunswick, Canada.

\section{GEOLOGICAL SETTING}

Wadi Um Addebaa area is located at $\sim 70$ $\mathrm{km} \mathrm{SW}$ of Marsa Alam City. It is accessible after $52 \mathrm{~km}$ to the south through the Red Sea Highway and then $32 \mathrm{~km}$ to the west through W. El Gemal.Wadi Um Addebaa intersected 
with W. El Gemal at the point $24^{\circ} 34^{\prime} 14^{\prime \prime} \mathrm{N}$ and $34^{\circ} 53^{\prime} 26^{\prime \prime} \mathrm{E}$. The peraluminous granite is well exposed within W. Um Addebaa at the intersection $24^{\circ} 34^{\prime} 31^{\prime \prime} \mathrm{N}$ and 34 $4^{\circ} 33^{\prime} 38^{\prime \prime} \mathrm{E}$.

The rocks exposed in Um Addebaa area (Fig.1) include: ophiolitic metagabbro (oldest), ophiolitic mélange, peraluminous granite and post granite dykes andveins (youngest).

The general geology of this area was described by many authors (Hume, 1934; Omar, 2001, Mahmoud, 2009 and Khaleal and Mahmoud 2009).

\section{The Ophiolitic Metagabbro}

The metagabbro is in mountain size and characterized by dark green color and medium to coarse grained. The metagabbro is thrusted over the ophiolitic mélange.

\section{The Ophiolitic Mélange}

The ophiolitic mélange composed of ophiolitic fragments of variable sizes comprising of serpentinites and metagabbro embedded in mélange matrix mainly of different varieties of schists (tourmaline-garnetiferous- biotiteschists). Petrographically, they are composed mainly of quartz, plagioclase and biotite.
Muscovite and chlorite are secondary minerals. Apatite, zircon and garnet are accessory minerals. They are similar to those in Nugrus-Sikait area described by Saleh (1997). Serpentinites are commonly altered into talc carbonates of creamy color. They are characterized by their cavernous nature. Sometimes instead of talc carbonates, the serpentinites are altered to talc-tremolite rock containing megascopic tourmaline (Fig.2).

\section{The Peraluminous Granites}

The peraluminous granites exposed as small bosses and dyke-like body $\left(<1.0 \mathrm{~km}^{2}\right)$ intruding the ophiolitic mélange at the middle part of the mapped area causing truncate the foliation of the schist at high angles. It is emplaced along N-S trend, about $250 \mathrm{~m}$ long and $60 \mathrm{~m}$ in width. The peraluminous granites are medium to coarse-grained or even pegmatitic and white in color forming mass of low relief (Fig. 3) with sharp intrusive contacts against the ophiolitic mélange. They are deformed and show well-known spheroidal weathering. The periphery, about $1 \mathrm{~m}$ wide, of the studied peraluminous granite is characterized by presence of monomineralic bandsof visible spessartine garnet (Fig. 4a\&b).

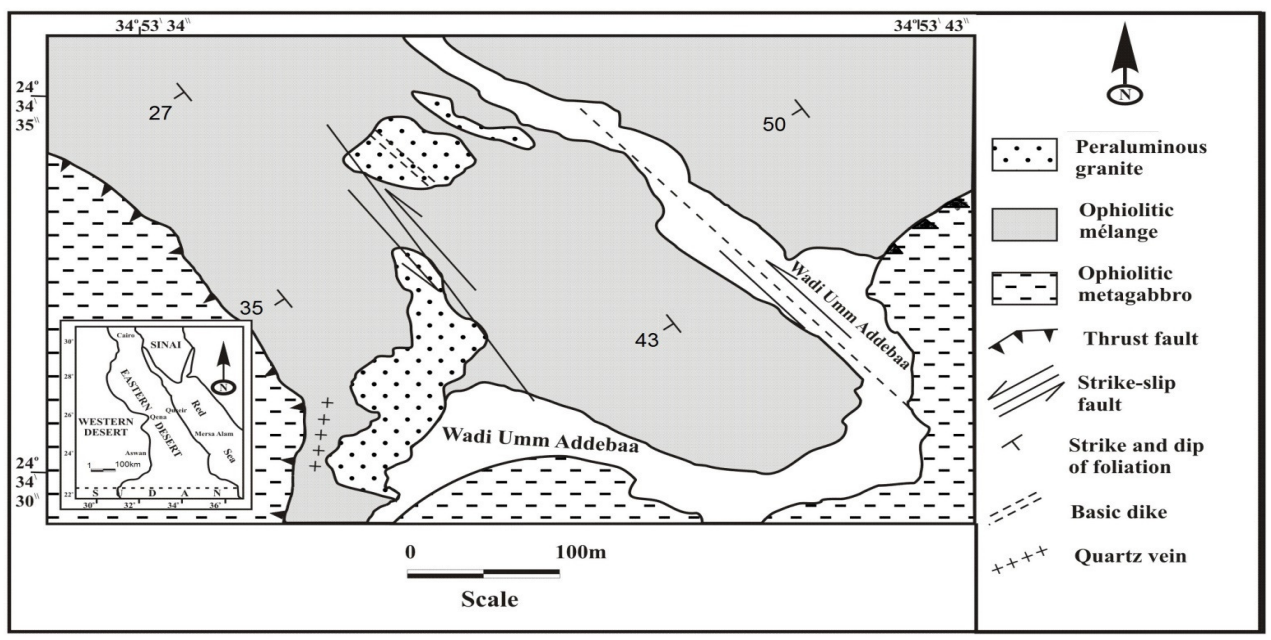

Fig. 1: Geologic map of Um Addebaa area, SED, Egypt (Modified after Mahmoud 2009) 


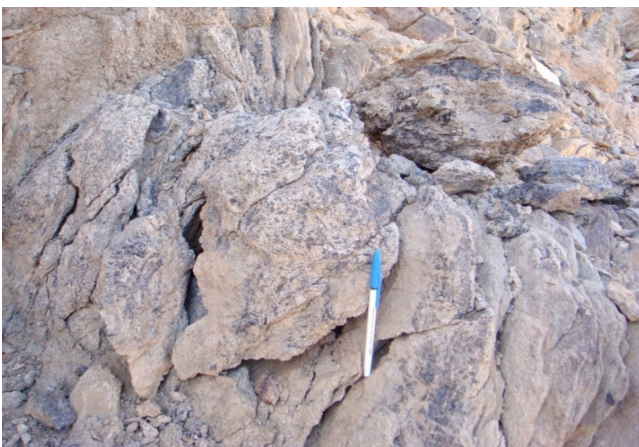

Fig. 2: Close-up view showing serpentinites altered to talc-tremolite rock containing megascopic tourmaline at W. Um Addebaa, SED, Egypt

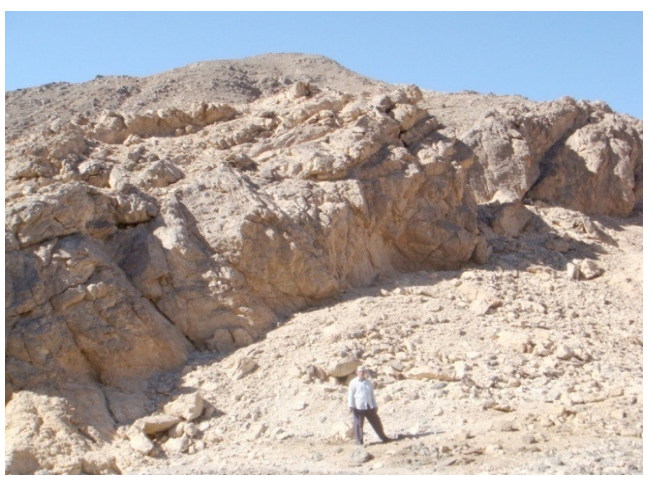

Fig. 3: Dike-like body of the peraluminous granite at W. Um Addebaa, SED, Egypt. Camera looking NNW

\section{PETROGRAPHY}

The peraluminous granites are medium to coarse-grained and mainly composed of $\mathrm{K}$ feldspar, sodic plagioclase (An 5-15), quartz, muscovite and biotite. Sericite and chlorite are secondary minerals. Tourmaline, zircon, allanite and garnet are common as accessory minerals. Myrmekitic texture is common. The presence of myrmekitic texture represents strong evidence for metasomatic origin, which are common in magmatic granite (Smith, 1974). Myrmekitic texture was formed due to the action of metasomatic processes with the exsolution around the margins of feldspar phenocrysts (Ashworth, 1979). Garnet; occurs as large oriented irregular crystals (Fig. 5) with pale pinkish color in plane polarized light, which appears in cracked or skeletal form (Fig. 6). The presence of muscovite as flakes reflects the peraluminous nature of these granites. The presence of two feldspars suggests that the peraluminous granites are mostly subsolvus and crystallized under high water pressure (Greenberge, 1981 and Deer et al., 1992). Locally, the granites are deformed and showing deformational features such as bent plagioclase lamellae, distorted microcline twinning, twisting of mica flakes, strongly undulatory quartz development of myrmekite and recrystallization of feldspars into fine-grained aggregates. All these features point to subsolidus deformation (Pater-
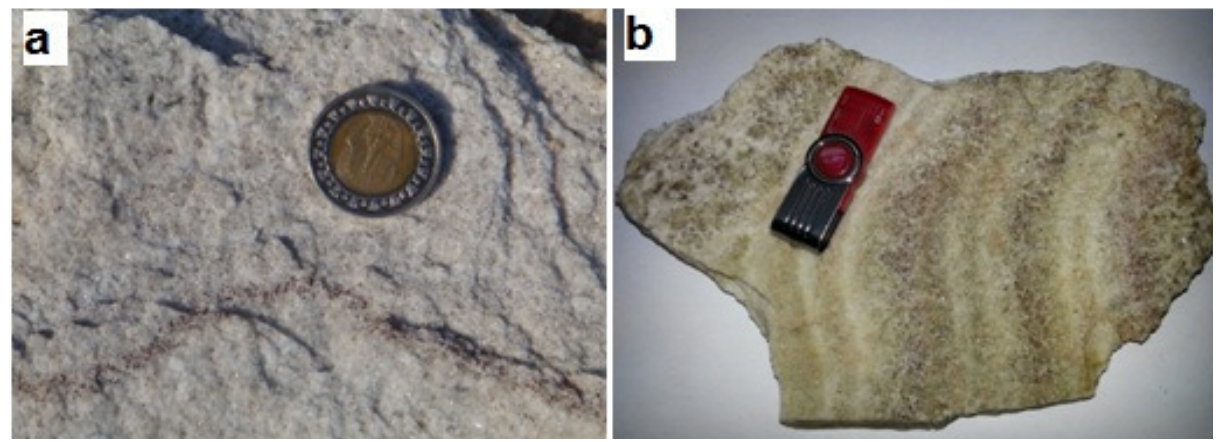

Fig. 4 (a\&b): Photos show monomineralic bands of garnet at the periphery of the peraluminous granite, Um Addebaa area, SED, Egypt 


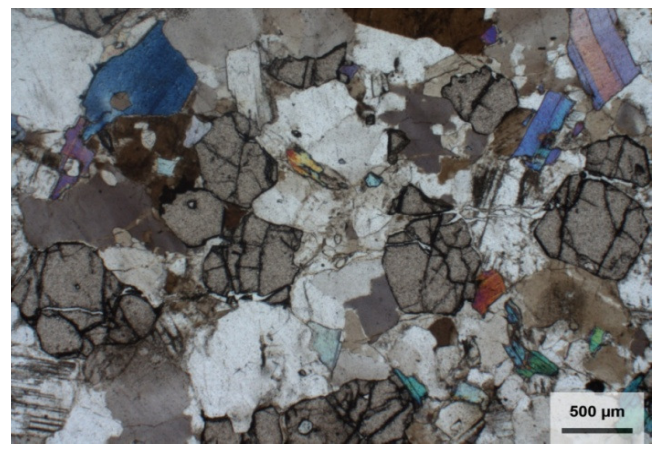

Fig. 5: Photomicrograph showing garnet crystals and muscovite in peraluminous granite in Um Addebaa area, SED, Egypt

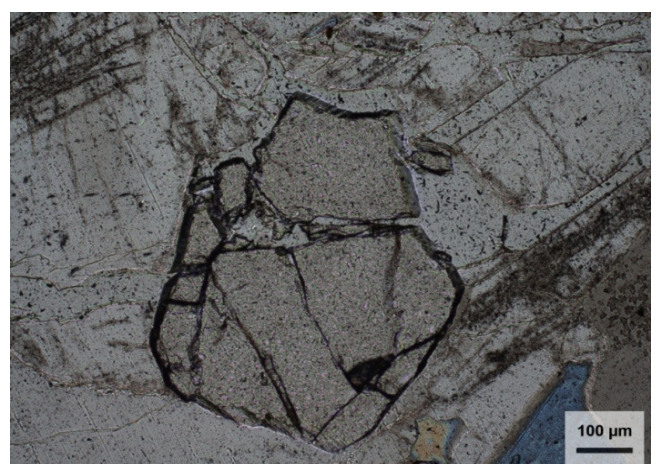

Fig. 6: Photomicrograph showing cracked crystal of spessartine in peraluminous granite, Um Addebaa area, SED, Egypt

son et al., 1989). Such deformation should be the result of extensive regional thrusting (Greiling et al., 1987), to which the area had been subjected.

The Post granite dykes and veins include basic dikes and quartz veins. Basic dykes cut across the peraluminous granite in the NW-SE direction. Quartz veins cut across the ophiolitic mélange. Some of them are beryl bearing veins -if present- they are usually surrounded by phlogopite schist which replaces tremolite-actinolite pockets, may be after a pyroxene protolith. The Wadi deposits of $\mathrm{W}$. Um Addebaa (about $3 \mathrm{~km}$ long), contains abundant beryl fragments as a result of ancient mines working.

\section{GEOCHEMISTRY}

The geochemical analyses of nine samples of peraluminous granites were carried out. The obtained data are listed in Table (1).

\section{Geochemical Characteristics}

The studied granite is relatively enriched in $\mathrm{SiO}_{2}, \mathrm{Al}_{2} \mathrm{O}_{3}, \mathrm{Na}_{2} \mathrm{O}$ and $\mathrm{K}_{2} \mathrm{O}$ contents and relatively low in $\mathrm{TiO}_{2}, \mathrm{MgO}, \mathrm{CaO}, \mathrm{FeO} \&$ $\mathrm{MnO}$ contents (Table 1). The relatively high content of alumina (av. 14.77\%) reflects the high muscovite and garnet contents, whereas the low concentrations of $\mathrm{Fe}_{2} \mathrm{O}_{3}, \mathrm{MgO}, \mathrm{CaO}$ and $\mathrm{TiO}_{2}$, reveal the lack of ferro-magnesium minerals. The relatively high $\mathrm{Na}$ and $\mathrm{K}$ content reflects the abundance of feldspar minerals. It displays enrichment in incompatible elements, especially $\mathrm{K}$ and $\mathrm{Rb}$ and depletion of High Field Strength Elements(HFSE) such as $\mathrm{Nb}$ and $\mathrm{Zr}$ (Table 1). It characterized by low contents of rare earth elements $(\mathrm{REE}=$ 3-29 ppm), (Table 1).

The studied peraluminous granite possesses an average $6.7 \mathrm{ppm}$ of $\mathrm{Be}$; so it is believed that this granite is the source of beryl mineralization in Wadi El Gemal area.

On the basis of R1-R2 discrimination diagram of De La-Roche et al. (1980), the studied peraluminous granitehas syenogranite to monzogranite characters (Fig. 7). According to Peccerillo and Taylor (1976), the most samples of the studied granite belong to calc-alkaline series (Fig. 8).

Based on Maniar and Piccoli, (1989), the studied granite samples fall in the peraluminous field (Fig. 9). According to binary variation diagram of Chappell and White (1974), the studied granite samples fall within the field of I-type granite (Fig. 10). Based on R1-R2 tectonic discrimination diagram of Bachelor and Bowden (1985), the studied 
Table 1: Geochemical analysis data of the peraluminous granite, Um Addebaa area, SED, Egyp

\begin{tabular}{|c|c|c|c|c|c|c|c|c|c|c|}
\hline & UDG-1 & UDG-2 & UDG-3 & UDG-4 & UDG-5 & UDG-6 & UDG-7 & UDG-8 & UDG-9 & Average \\
\hline & \multicolumn{10}{|c|}{ Major Oxides } \\
\hline $\mathrm{SiO}_{2}$ & 73.15 & 72.8 & 74.59 & 72.75 & 75.42 & 75.27 & 74.35 & 73.78 & 74.45 & 74.06 \\
\hline $\mathrm{Al}_{2} \mathrm{O}_{3}$ & 14.9 & 14.72 & 14.92 & 14.54 & 14.87 & 14.95 & 14.72 & 14.56 & 14.76 & 14.77 \\
\hline $\mathrm{Fe}_{2} \mathrm{O}_{3}(\mathrm{~T})$ & 2.08 & 2.1 & 1.41 & 1.84 & 0.97 & 0.98 & 0.73 & 0.89 & 0.94 & 1.33 \\
\hline $\mathrm{MnO}$ & 0.816 & 0.851 & 0.475 & 0.566 & 0.176 & 0.082 & 0.102 & 0.111 & 0.123 & 0.37 \\
\hline MgO & 0.09 & 0.09 & 0.07 & 0.07 & 0.13 & 0.12 & 0.07 & 0.11 & 0.07 & 0.09 \\
\hline $\mathrm{CaO}$ & 1.13 & 1.2 & 1.23 & 1.17 & 1.36 & 1.44 & 1.38 & 1.46 & 1.39 & 1.31 \\
\hline $\mathrm{Na}_{2} \mathrm{O}$ & 4.04 & 4.42 & 4.71 & 4.44 & 5.28 & 5.53 & 5.4 & 5.52 & 5.37 & 4.97 \\
\hline $\mathrm{K}_{2} \mathrm{O}$ & 2.67 & 2.35 & 2.63 & 2.68 & 1.85 & 1.71 & 1.81 & 1.47 & 1.6 & 2.09 \\
\hline $\mathrm{TiO}_{2}$ & 0.017 & 0.011 & 0.011 & 0.012 & 0.013 & 0.016 & 0.005 & 0.016 & 0.013 & 0.01 \\
\hline $\mathrm{P}_{2} \mathrm{O}_{5}$ & 0.05 & 0.04 & 0.03 & 0.05 & 0.05 & 0.06 & 0.03 & 0.03 & 0.04 & 0.04 \\
\hline LOI & 1.27 & 1.2 & 0.93 & 0.97 & 0.79 & 0.82 & 0.31 & 0.93 & 0.86 & 0.9 \\
\hline \multirow[t]{2}{*}{ Total } & 100.2 & 99.76 & 101 & 99.08 & 100.9 & 101 & 98.9 & 98.87 & 99.62 & 99.93 \\
\hline & \multicolumn{10}{|c|}{ Trace Elements } \\
\hline Au & $<1$ & 10 & $<1$ & $<1$ & $<1$ & $<1$ & $<1$ & $<1$ & $<1$ & 10 \\
\hline $\mathbf{A g}$ & $<0.5$ & $<0.5$ & $<0.5$ & $<0.5$ & $<0.5$ & $<0.5$ & $<0.5$ & $<0.5$ & $<0.5$ & 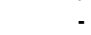 \\
\hline As & 25 & 23 & 31 & 52 & 2 & 10 & 1 & $<1$ & 3 & 18.38 \\
\hline $\mathbf{B a}$ & 18 & 16 & 14 & 16 & 15 & 42 & 12 & 18 & 11 & 18 \\
\hline $\mathrm{Be}$ & 6 & 6 & 6 & 5 & 7 & 12 & 6 & 6 & 6 & 6.67 \\
\hline Bi & 22 & 15 & 24 & 28 & 38 & 30 & 32 & 35 & 35 & 28.78 \\
\hline $\mathrm{Br}$ & 2.4 & $<0.5$ & $<0.5$ & $<0.5$ & $<0.5$ & $<0.5$ & $<0.5$ & $<0.5$ & $<0.5$ & 2.4 \\
\hline Cd & 1.1 & 1.1 & 1 & 1.2 & $<0.5$ & $<0.5$ & $<0.5$ & $<0.5$ & $<0.5$ & 1.1 \\
\hline Co & $<0.1$ & 2.6 & $<0.1$ & $<0.1$ & 3.2 & $<0.1$ & $<0.1$ & $<0.1$ & $<0.1$ & 2.9 \\
\hline $\mathrm{Cr}$ & 37.3 & 51.9 & $<0.5$ & 42.9 & $<0.5$ & 18.1 & $<0.5$ & 17.4 & 16.5 & 30.68 \\
\hline Cs & 9.5 & 6.1 & 8.6 & 8.2 & 5.9 & 7.8 & 6.6 & 3.3 & 6.3 & 6.92 \\
\hline $\mathrm{Cu}$ & 15 & 12 & 13 & 21 & $<1$ & 4 & 8 & 3 & $<1$ & 10.86 \\
\hline Hf & 11.8 & 11.1 & 8.7 & 9.6 & 12.2 & 9.7 & 8.6 & 8.3 & 9.3 & 9.92 \\
\hline $\mathrm{Hg}$ & $<1$ & $<1$ & $<1$ & $<1$ & $<1$ & $<1$ & $<1$ & $<1$ & $<1$ & 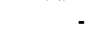 \\
\hline Ir & $<1$ & $<1$ & $<1$ & $<1$ & $<1$ & $<1$ & $<1$ & $<1$ & $<1$ & - \\
\hline Mo & $<2$ & $<2$ & $<2$ & $<2$ & $<2$ & $<2$ & $<2$ & $<2$ & $<2$ & - \\
\hline $\mathrm{Ni}$ & 3 & 3 & 2 & 3 & 3 & 2 & 4 & 3 & 1 & 2.67 \\
\hline $\mathrm{Pb}$ & 130 & 102 & 135 & 159 & 47 & 64 & 54 & 49 & 48 & 87.56 \\
\hline $\mathbf{R b}$ & 390 & 300 & 330 & 310 & 220 & 220 & 230 & 220 & 160 & 264.44 \\
\hline Sn & 11 & 13 & 8 & 10 & 7 & 6 & 5 & 6 & 5 & 7.89 \\
\hline Sb & 0.3 & 0.4 & 0.7 & 0.7 & $<0.1$ & 1 & $<0.1$ & 0.2 & $<0.1$ & 0.55 \\
\hline S & 0.156 & 0.083 & 0.106 & 0.129 & 0.016 & 0.031 & 0.019 & 0.016 & 0.011 & 0.06 \\
\hline Sc & 9.05 & 8.66 & 6.33 & 7.01 & 5 & 2.97 & 3.23 & 2.95 & 3.61 & 5.42 \\
\hline Se & $<0.5$ & $<0.5$ & 13.8 & 12.4 & 6.1 & 6.4 & $<0.5$ & $<0.5$ & $<0.5$ & 9.68 \\
\hline $\mathrm{Sr}$ & 27 & 27 & 28 & 28 & 24 & 37 & 22 & 26 & 21 & 26.67 \\
\hline Nb & 21 & 19 & 15 & 18 & 16 & 28 & 14 & 14 & 13 & 17.56 \\
\hline Ta & $<0.3$ & $<0.3$ & 2.8 & $<0.3$ & $<0.3$ & 10.3 & $<0.3$ & $<0.3$ & $<0.3$ & 6.55 \\
\hline Th & 4.7 & 2.9 & 4 & 3.5 & 5.2 & 5.7 & 4.4 & 4.2 & 5.4 & 4.44 \\
\hline $\mathbf{U}$ & 20.4 & 17 & 16.3 & 15.8 & 25.6 & 23.2 & 16.8 & 17.4 & 18.2 & 18.97 \\
\hline V & 13 & 7 & 6 & 8 & 14 & 7 & 6 & 7 & 6 & 8.22 \\
\hline W & $<1$ & $<1$ & $<1$ & $<1$ & $<1$ & $<1$ & $<1$ & $<1$ & $<1$ & \\
\hline Ga & 34 & 33 & 28 & 31 & 28 & 26 & 26 & 26 & 27 & 28.78 \\
\hline $\mathbf{Y}$ & 392 & 415 & 255 & 295 & 155 & 77 & 97 & 102 & 112 & 211.11 \\
\hline Zn & 338 & 282 & 322 & 418 & 49 & 102 & 58 & 47 & 47 & 184.78 \\
\hline \multirow[t]{2}{*}{$\mathrm{Zr}$} & 171 & 137 & 124 & 131 & 200 & 140 & 115 & 120 & 128 & 140.67 \\
\hline & \multicolumn{10}{|l|}{ REES } \\
\hline La & 8.24 & 5.79 & 6.16 & 6.75 & 8.08 & 8.31 & 6.41 & 5.95 & 6.86 & 6.95 \\
\hline $\mathrm{Ce}$ & 46 & 34 & 35 & 31 & 26 & 23 & 21 & 20 & 24 & 28.89 \\
\hline Nd & 12 & 10 & 16 & 18 & 20 & 20 & 12 & 10 & 12 & 14.44 \\
\hline $\mathrm{Sm}$ & 9.03 & 7.34 & 6.9 & 7.33 & 7.89 & 6.56 & 6.32 & 5.88 & 6.84 & 7.12 \\
\hline Eu & $<0.2$ & $<0.2$ & $<0.2$ & $<0.2$ & $<0.2$ & $<0.2$ & $<0.2$ & $<0.2$ & $<0.2$ & . \\
\hline $\mathrm{Tb}$ & 8.2 & 10.3 & 6.3 & 6.8 & 4 & 2.9 & 2.9 & 2.7 & 3.3 & 5.27 \\
\hline $\mathbf{Y b}$ & 24.6 & 24.1 & 17.2 & 19.5 & 11.8 & 5.26 & 7.28 & 7.36 & 8.16 & 13.92 \\
\hline $\mathbf{L u}$ & 4.51 & 4.26 & 3.36 & 3.65 & 2.76 & 1.54 & 1.71 & 1.8 & 2.09 & 2.85 \\
\hline
\end{tabular}




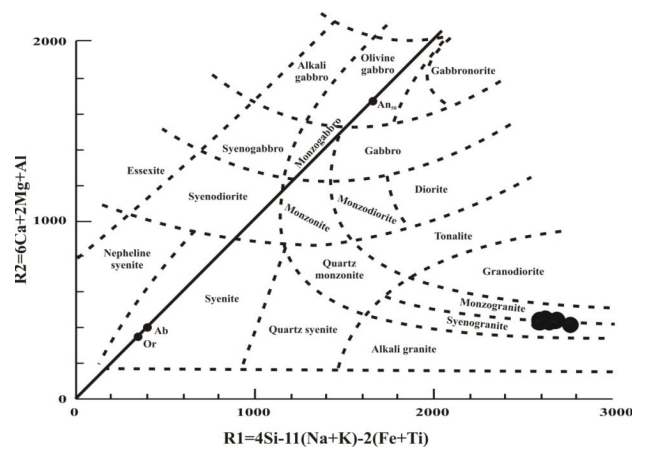

Fig. 7: $\mathrm{R}_{1}-\mathrm{R}_{2}$ diagram for the studied granodiorite and monzogranite according to De La Roche et al. (1980)

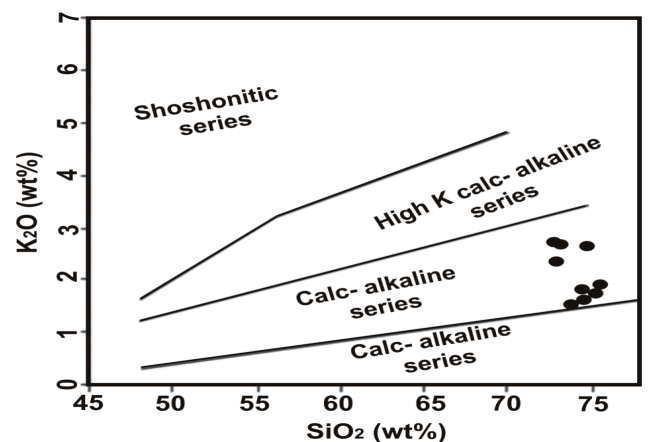

Fig. 8: $\mathrm{SiO}_{2}$ versus $\mathrm{K}_{2} \mathrm{O}$ diagram according to Peccerillo and Taylor (1976) for the studied peraluminous granite, Um Addebaa area, SED, Egypt

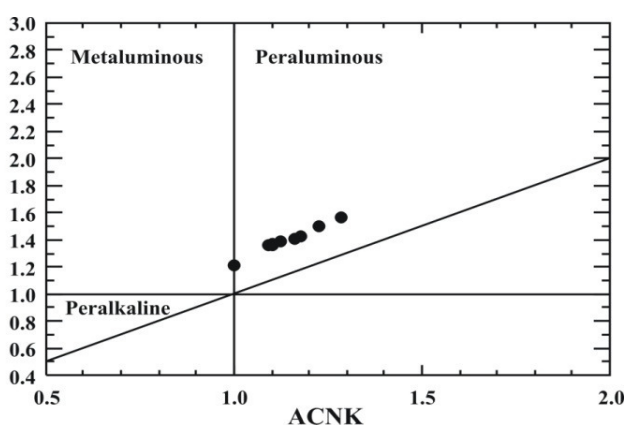

Fig. 9: A/NK vs. A/CNK binary diagram for the studied peraluminous granites, according to Maniarand Piccoli, (1989), Um Addebaa area, SED, Egypt

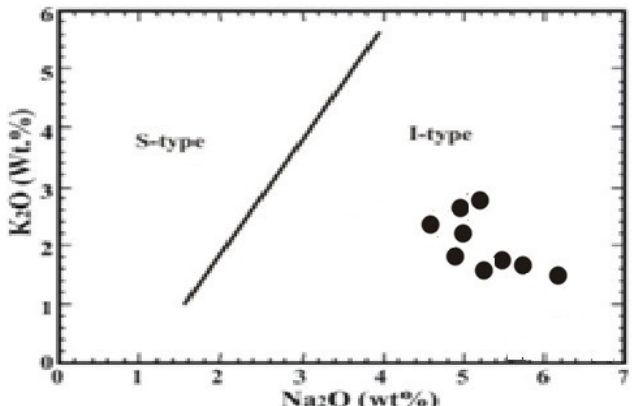

Fig. 10: $\mathrm{K}_{2} \mathrm{O}$ vs. $\mathrm{Na}_{2} \mathrm{O}$ binary variation diagram (according to Chappel and White, 1974) of the studied peraluminous granites, Um Addebaa area, SED, Egypt

granite belongs to Syn-collision setting field (Fig. 11). According to Ab-Qz-Or diagram of Tuttle and Bowen (1958) and after Luth et al., (1964) the studied granite emplaced at relatively shallower depth (water pressure 3 - $2 \mathrm{~kb}$; Fig. 12) in the crust and crystallized at temperature range from 800 to $760 \mathrm{C}^{\circ}$ (Fig. 13).

Based on the spiderdiagram of normalized trace elements relative to the chondrites of Thompson (1982), the studied granite shows a marked enrichment of $\mathrm{Rb}, \mathrm{Th}, \mathrm{K}, \mathrm{La}, \mathrm{Ce}, \mathrm{Nd}$, $\mathrm{Tb}, \mathrm{Yb}, \mathrm{Sm}, \mathrm{Hf}$ and $\mathrm{Y}$ and a marked deple-

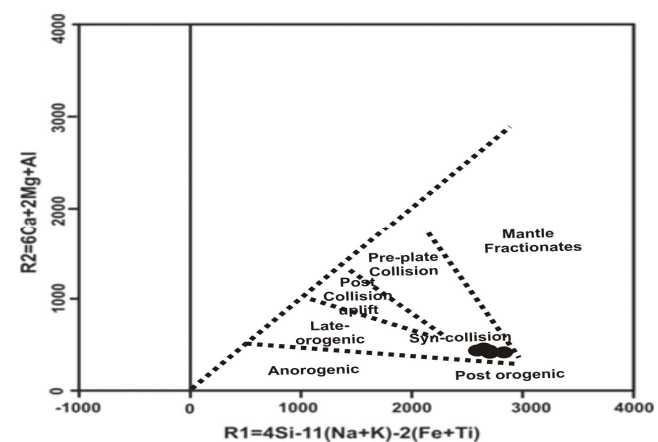

Fig. 11: R1-R2 diagram according to Bachelor \& Bowden (1985) of tectonic settings of the studied peraluminous granite, Um Addebaa area, SED, Egypt 


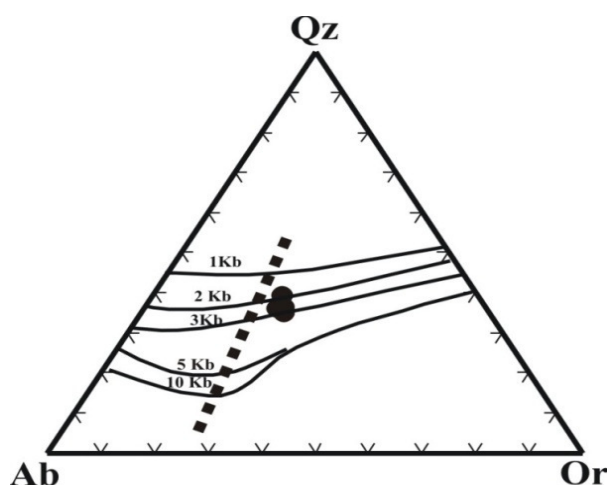

Fig. 12: Ab-Qz-Or diagram for the studied granite. The dashed lines represent the minimum melting points in the granite system at different water-vapor pressure. $1,2 \& 3 \mathrm{~kb}$ according to Tuttle and Bowen (1958), 5\&10 kb according to Luth et al. (1964), Um Addebaa area, SED, Egypt

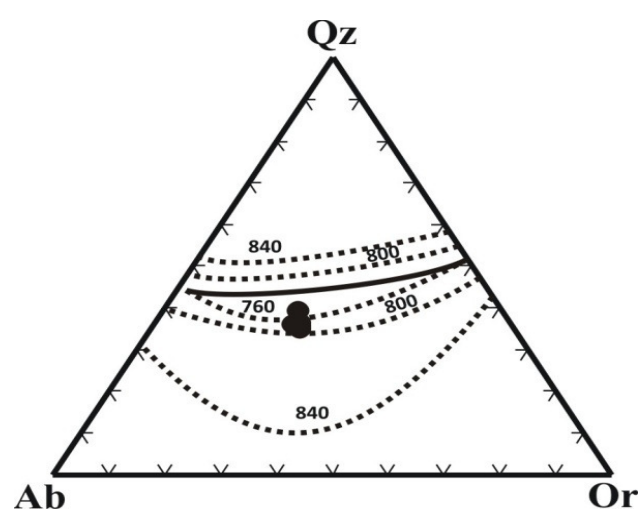

Fig. 13: Ab-Qz-Or diagram for the studied granite, according to Luth et al., (1964), Um Addebaa area, SED, Egypt

tion of $\mathrm{Ti}$, whereas $\mathrm{Sr}$ and $\mathrm{Ba}$ values around the unity (Fig. 14).

According to spider diagram plot of Taylor \& McLennan (1985) the studied granitesare characterized by high content of $\mathrm{Cs}, \mathrm{Rb}$, $\mathrm{U}, \mathrm{Tb}, \mathrm{Y}, \mathrm{Yb}$ and moderate enrichment of $\mathrm{Ta}$, Hf, Sm \& K. Otherwise, it has very depletion in $\mathrm{Ba}$, $\mathrm{Ti} \& \mathrm{Sr}$ while it has moderate depletion of $\mathrm{La}, \mathrm{Ce} \& \mathrm{Nd}$ (Fig. 15). The strong enrichment content of some elements isdue to

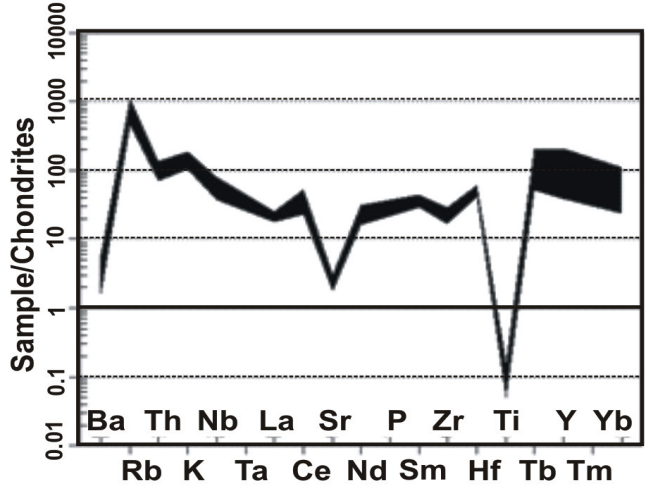

Fig. 14: Spider diagram of normalized trace elements for studied peraluminous granite, Um Addebaa area, SED, Egypt. Samples are normalized to chondrites of Thompson (1982)

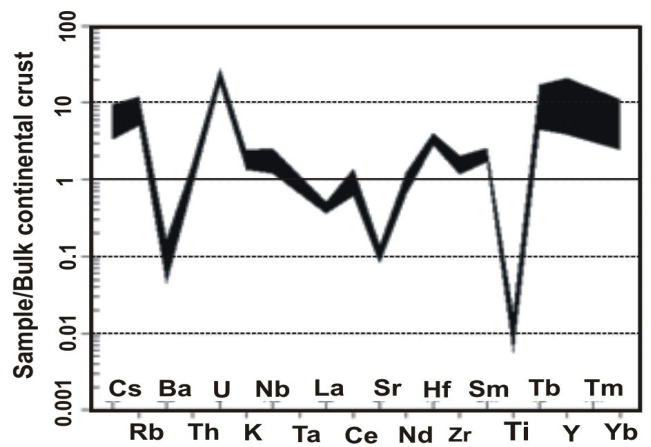

Fig. 15: Spider diagram of normalized REE for studied peraluminous granite, Um Addebaa area, SED, Egypt. Samples are normalized to Bulk continental crust of Taylor and McLennan, (1995)

the presence of some accessory minerals as xenotime and zircon.

\section{RADIOMETRY}

\section{Spectrometric Study}

Gamma-ray spectrometry has been carried out on the studied peraluminous granite, using GS-512 spectrometer. The measurements are expressed in $\mathrm{ppm}$ for $\mathrm{eU}$ 
\& eTh and in percent for $\mathrm{K}$ (Table 2). The radioelements of the peraluminous granites possess high average values of the $\mathrm{K} \%$, eU, eTh contents and their ratios. The average values of eU content are higher than the average values of eTh content. The relation of the radioelement concentrations in the studied peraluminous granite to those of the crustal igneous rocks after IAEA (1979), Boyle (1982), Adams et al. (1959) and Clarke et al. (1966) are listed in Table (2) and shows the following features:- The average values of $\mathrm{K}$, eTh contents are the lesser than those the corresponding values in the crustal average, while the average values of eU content are higher than those the corresponding values in the crustal average. The average values of $\mathrm{eU} / \mathrm{eTh}$ ratios in the peraluminous granites are more than that the corresponding values in the crustal average. The average value of the eU content of the peraluminous granites are higher than the twice Clarke (Clarke value for $\mathrm{eU}=4 \mathrm{ppm}$ and $\mathrm{eTh}=18-20 \mathrm{ppm}$ ), but the average values of the eTh content are lesser than the twice Clarke values. From the above correlation (Table 3 ), we can conclude that the peraluminous granites at Um Addebaa area are relatively abnormal case as the corresponding values in the crustal average and there are some high values of radioactive elements. The termuraniferous should be applied to this granite, which contains eU (12 ppm) higher than twice of Clarke value. The term fertile should be applied according to Gangloff (1970), where the uranium content varies between 4-22 ppm.

The correlation diagrams of eU vs. eTh, eU vs. eU/eTh and eTh vs. eU/eTh are shown on Figs. (16 -18). From these diagrams, the following could be sUmarized:-

Plot of eU vs. eTh correlation diagram showed that there is strongly positive correlation $(r=0.63)$ between eU and eTh in the peraluminous granite. Plot of eU vs. eU/eTh correlation diagram showed that there is moderately positive correlation $(r=0.44)$ between $\mathrm{eU}$ and $\mathrm{eU} / \mathrm{eTh}$ ratio in the peralumi-
Table 2: Statistics of spectrometric data and their ratios of the peraluminous granite at Um Addebaa area, Um Addebaa area, SED, Egypt

\begin{tabular}{|c|c|c|c|c|c|c|}
\hline & \multicolumn{6}{|c|}{ Peraluminous granite $(\mathrm{N}=\mathbf{2 0})$} \\
\hline & $\mathbf{K} \%$ & $\begin{array}{r}\mathrm{eU} \\
(\mathrm{ppm})\end{array}$ & $\begin{array}{r}\text { eTh } \\
(\mathrm{ppm})\end{array}$ & eU/eTh & eTh/eU & $\mathrm{eTh} / \mathrm{K}$ \\
\hline Minimum (Min.) & 1 & 4 & 3 & 0.80 & 0.24 & 1.14 \\
\hline Maximum (Max.) & 5.5 & 22 & 15 & 4.30 & 1.33 & 3 \\
\hline Range & $1-5.5$ & 4-22 & 3-15 & $0.80-4.30$ & $0.24-1.33$ & 1.14-3 \\
\hline $\operatorname{Mean}(\mathbf{X})$ & 3.93 & 12.77 & 7.77 & 1.80 & 0.67 & 1.95 \\
\hline \multicolumn{7}{|c|}{ Crustal acidic igneous rocks (after IAEA, 1979 and Boyle, 1982) } \\
\hline Average & 4 & 4.5 & 18 & 0.25 & . & 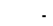 \\
\hline Range & . & $1-12$ & $5-20$ & $0.1-0.5$ & . & - \\
\hline \multicolumn{7}{|c|}{ Adams et al, 1959 Clarke et.al, 1966} \\
\hline Average & . & 4 & 19 & 0.25 & . & - \\
\hline Range & . & $1-9$ & $18-20$ & . & . & . \\
\hline
\end{tabular}

$\mathbf{N}=$ number of measurements

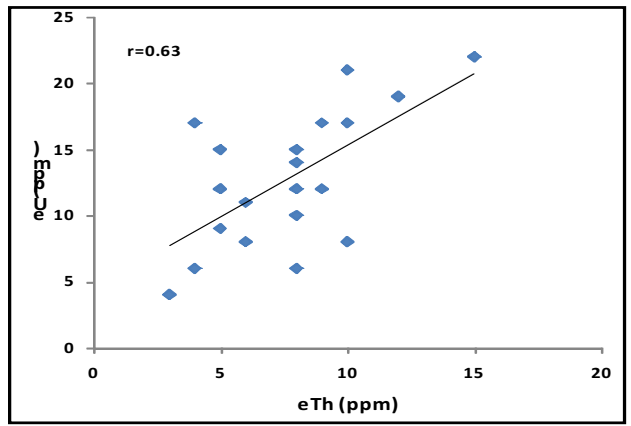

Fig. 16: Correlation diagram of eTh vs. eU of the peraluminous granite, Um Addebaa area, SED, Egypt

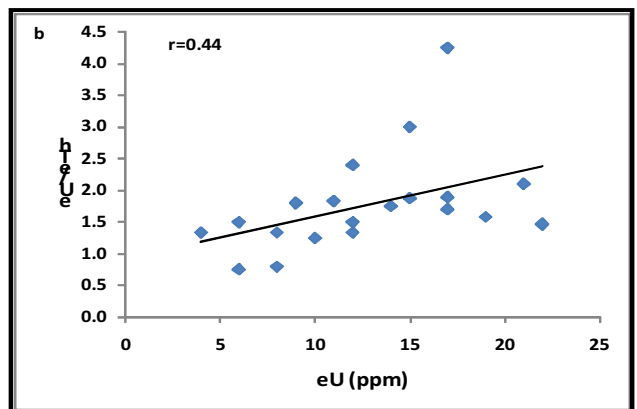

Fig. 17: Correlation diagram of eU vs. eU/eTh of the peraluminous granite, Um Addebaa area, SED, Egypt 


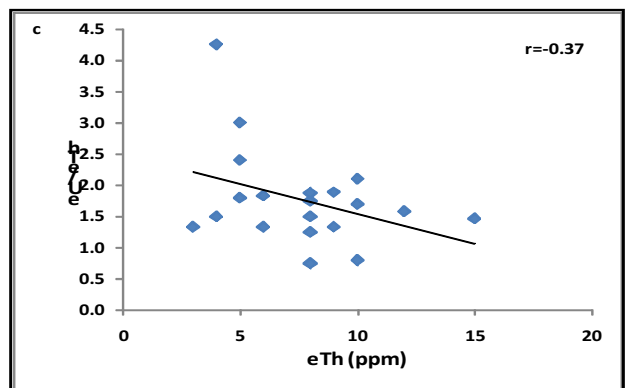

Fig. 18: Correlation diagram of eTh vs. eU/eTh of the peraluminous granite,Um Addebaa area, SED, Egypt

nous granite. Plot of eTh vs. eU/eTh correlation diagram showed that there is moderate negative correlation $(\mathrm{r}=-0.37)$ between $\mathrm{eTh}$ and $\mathrm{eU} / \mathrm{eTh}$ ratio in the peraluminous granite (Khaleal and Mahmoud, 2009).

\section{Geochemical Distribution of Uranium and Thorium}

From Table (1), the peraluminous granite samples show $U$ content ranging from $15.8-25.6$ with an average of 18.9 , while Th content ranging from 2.9 to 5.7 with an average of 4.4. Also, this agrees with the spectrometric values that $U$ content is more than Th content. The high $\mathrm{U} / \mathrm{Th}$ ratio of the peraluminous granite may be due to their enrichment in radioactive accessory minerals such as zircon, xenotime and allanite.

\section{MINERALOGY}

Microscopic investigations, scanning electron microscopy (SEM), and electron probe micro-analyses (EPMA) were used to identify and study minerals present in the peraluminous granite.

Generally, some minerals such as beryl and tourmaline are observed by naked eye in the ophiolitic mélange surrounding the peraluminous granite. In the peraluminous granite itself, garnet (spessartine) is observed also by naked eye. Other some minerals such as zir- con and xenotime are detected by SEM.

Spessartine $\mathrm{Mn}_{3}^{+2} \mathrm{Al}_{2}\left(\mathrm{SiO}_{4}\right)_{3}$ is reddish orange in color (Fig. 19). It was confirmed by XRD techniques (Fig. 20). SEM technique is used for analyzing the garnet crystalsfrom core to rim \{Figs. $21(\mathrm{a}-\mathrm{d})$ and Table 3 \} as indicating by Zoning in spessartine crystals. The composition differsfrom core to the rime due to the variation in the ratio of $\mathrm{Fe}$ and $\mathrm{CaO}$. As $\mathrm{Mn}$ increases in the core more than the rim whereas Fe indicates vice versa, i. e. it increases in the rim and decrease in the core. Zircon (Figs. 22.a\&b) and xenotime (Fig. 23) are also recorded in the peraluminous granites. Tables (4\&5) show scan analysis values for muscovite and uranium oxide detected in the studied peraluminous granite, respectively.

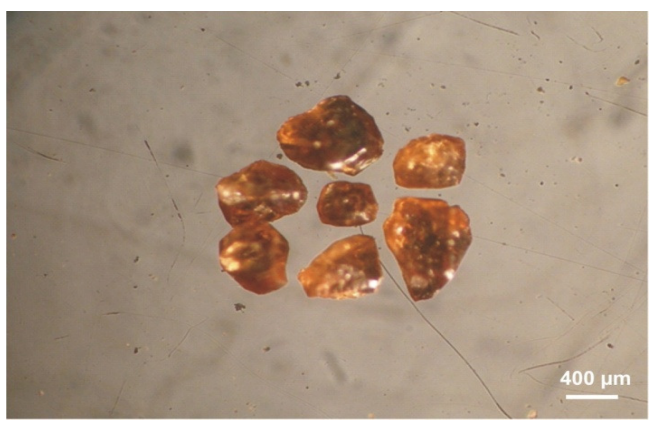

Fig. 19: Reddish orange colored spessartine garnet in peraluminous granites at Um Addebaa area, SED, Egypt

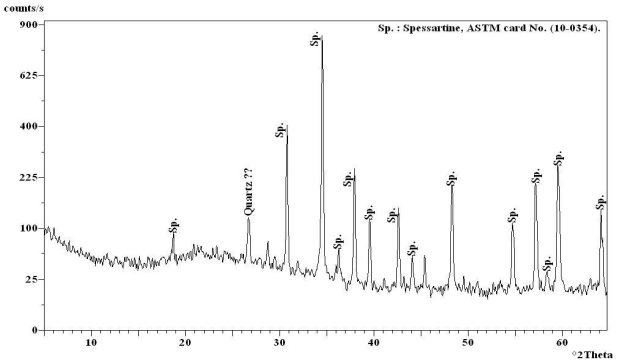

Fig. 20: XRD pattern for garnet (spessartine) in peraluminous granites in Um Addebaa area, SED, Egypt 

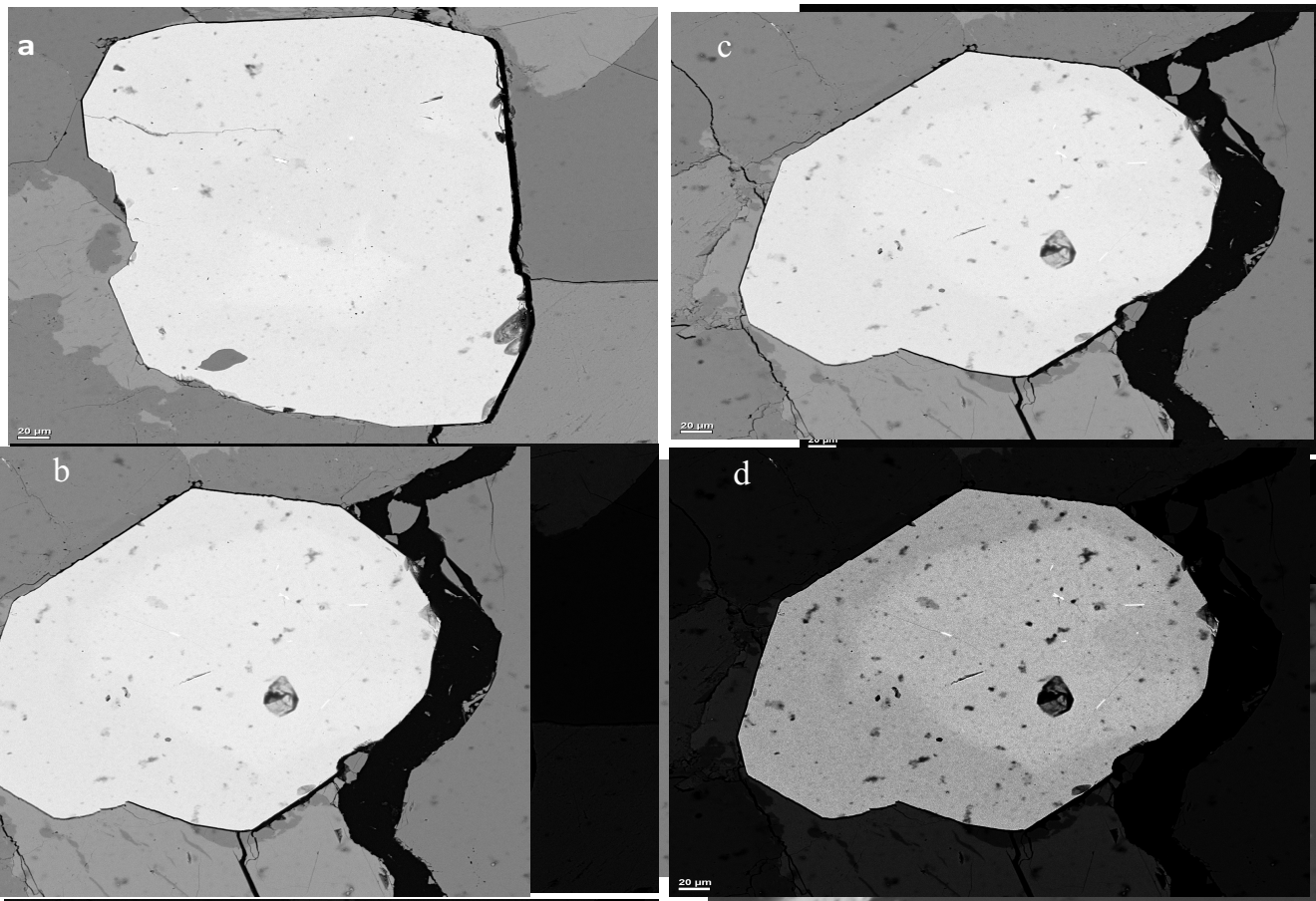

Fig. 21 (a-d): SEM photos of spessartine in peraluminous granites in Um Addebaa area, SED, Egypt. Note zoning from core to rim on Figs $(b \& d)$

Table 3: Scan analysis values of spessartine (core and rim) in the studied peraluminous granites

\begin{tabular}{|c|c|c|c|c|c|c|c|c|c|}
\hline Sample & $\mathrm{MgO}$ & $\overline{\mathrm{Al}_{2} \mathrm{O}_{3}}$ & $\mathrm{SiO}_{2}$ & $\mathrm{Y}_{2} \mathrm{O}_{3}$ & $\mathrm{CaO}$ & $\mathrm{TiO}_{2}$ & $\mathrm{MnO}$ & $\mathrm{FeO}$ & Total \\
\hline UDG1-Core & 0.32 & 20.6 & 36.07 & 0.43 & 4.9 & 0.14 & 15.89 & 21.7 & 100.05 \\
\hline UDG1-Rim & 0.45 & 20.52 & 35.78 & 0.35 & 1.76 & 0.15 & 13.75 & 26.8 & 99.56 \\
\hline UDG2-Core & 0.45 & 20.46 & 35.51 & 1.75 & 2.94 & 0.17 & 11.71 & 26.12 & 99.12 \\
\hline UDG2-Rim & 0.35 & 20.48 & 36.34 & 0,37 & 2.36 & 0.21 & 12.73 & 27.03 & 99.85 \\
\hline UDG3-Core & 0.36 & 20.37 & 35.24 & 1.97 & 3.59 & 0.12 & 12.61 & 23.57 & 97.83 \\
\hline UDG3-Rim & 0.28 & 20.56 & 35.97 & 0.33 & 1.54 & 0.24 & 13.45 & 27.05 & 99.43 \\
\hline UDG4-Core & 0.44 & 20.67 & 35.75 & 1.64 & 3.42 & 0.13 & 18.78 & 18.8 & 99.63 \\
\hline UDG4-Rim & 0.43 & 20.75 & 35.99 & 0.8 & 2.14 & 0.28 & 17.44 & 22.6 & 100.43 \\
\hline UDG5-Core & 0.28 & 20.46 & 35.71 & 1.38 & 3.54 & 0.29 & 18.22 & 18.84 & 98.72 \\
\hline UDG5-Rim & 0.36 & 20.82 & 36.29 & 0.28 & 1.73 & 0.14 & 16.93 & 23.86 & 100.4 \\
\hline UDG6-Core & 0.73 & 20.82 & 35.16 & 2.27 & 3.49 & 0.26 & 7.8 & 29.46 & 100 \\
\hline UDG6-Rim & 0.4 & 20.68 & 36.31 & 0.49 & 2.31 & 0.18 & 7.89 & 30.96 & 99.21 \\
\hline UDG9-Core & 0.33 & 20.62 & 36.22 & 0.48 & 3.27 & 0.12 & 6.33 & 31.93 & 99.21 \\
\hline UDG9-Rim & 0.35 & 20.24 & 35.53 & 0.54 & 1.46 & 0.2 & 8.6 & 30.71 & 97.64 \\
\hline
\end{tabular}



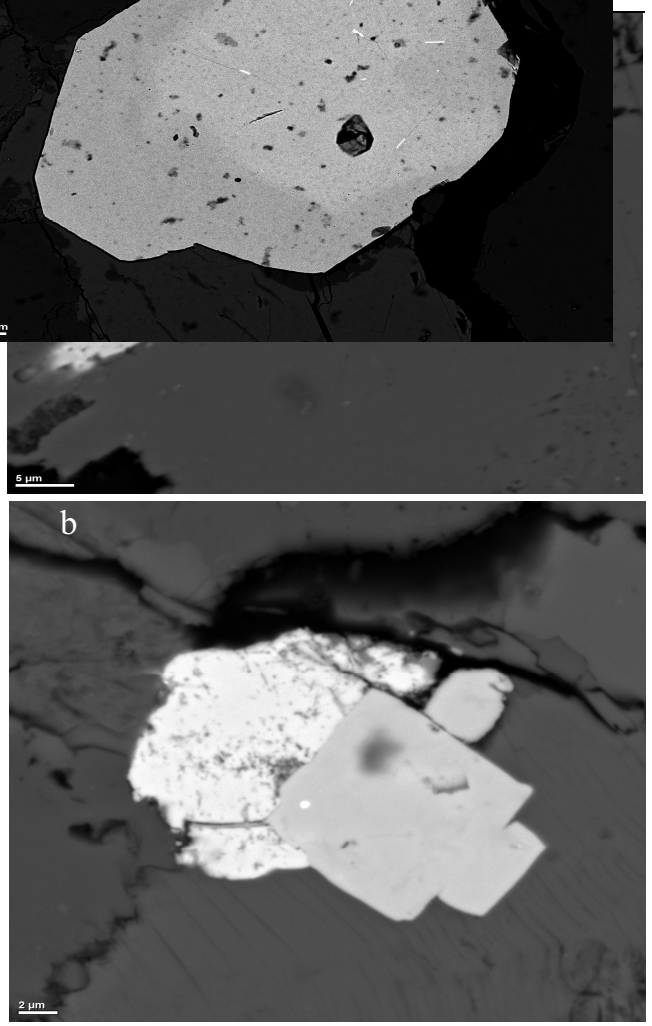

Fig. $22(\mathrm{a} \& \mathrm{~b})$ : SEM photos of zircon in peraluminous granite at W. Um Addebaa area, SED, Egypt

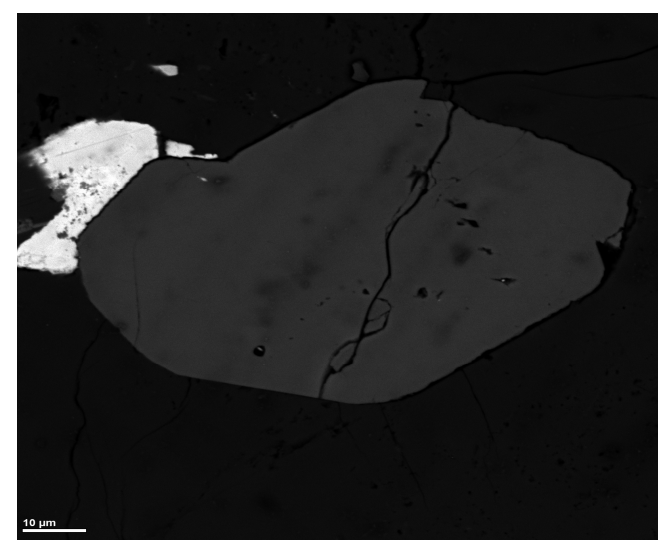

Fig. 23: SEM photo of xenotime in peraluminous granite at W. Um Addebaa area, SED, Egypt
Table 4: Scan analysis values of muscovite in the studied peraluminous granites

\begin{tabular}{lrrrrrrrr}
\hline Sample & $\mathrm{Na}_{2} 0$ & $\mathrm{Mg}_{2} 0$ & $\mathrm{AL}_{2} \mathrm{O}_{3}$ & $\mathrm{Si}_{2}$ & $\mathrm{~K}_{2} 0$ & $\mathrm{Mn} 0$ & $\mathrm{Fe} 0$ & Total \\
\hline UDG9Musc. & 0.29 & 0.62 & 333.29 & 46.97 & 10 & 0.43 & 3 & 94.6 \\
\hline
\end{tabular}

Table 5: Scan analysis values of uranophane in the studied peraluminous granites

\begin{tabular}{lcccccr}
\hline Sample & $\mathrm{Si}_{2}$ & $\mathrm{Y}_{2} \mathrm{O}_{3}$ & $\mathrm{ZrO}_{2}$ & $\mathrm{pb0}$ & $\mathrm{UO}_{2}$ & Total \\
\hline $\begin{array}{l}\text { UDG2 Uranium } \\
\text { 0xide }\end{array}$ & 3.71 & 7.18 & 3.91 & 6.88 & 76.42 & 98.1 \\
\hline
\end{tabular}

\section{MICROPROBE STUDY}

Mineral composition for many grains of garnet are determined on the JEOL JXA-733 Superprobe; operating conditions (Table, 6) at the Microscopy and Microanalyses Facility, University of New Brunswick (UNB), Fredericton, New Brunswick, Canada. The aim of the microprobe analysis is to contrast the garnet chemistry and/or composition for different parts of the peraluminous granites and also to get a better understanding of its final concentrate composition.

Three grains of garnet are chemically analyzed by microprobe along profiles \{Fig. 24 (A-C) $\}$. For each grain, eight element oxides are analyzed at the laboratories of UNB, Canada. The data is listed in Table (7). Generally, garnet is mainly spessartine with a core rich in $\mathrm{CaO}, \mathrm{MgO}, \mathrm{TiO}_{2}$ and $\mathrm{Y}_{2} \mathrm{O}_{3}$, while the rim is enriched in $\mathrm{FeO}$ and $\mathrm{Al}_{2} \mathrm{O}_{3}$ and $\mathrm{SiO}_{2} . \mathrm{MnO}$ shows variable enrichment.

Some bar diagrams were constructed to illustrate some ratios of oxides in the studied spessartine grains (Figs 25-27).

Table 6: Microprobe analysis conditions

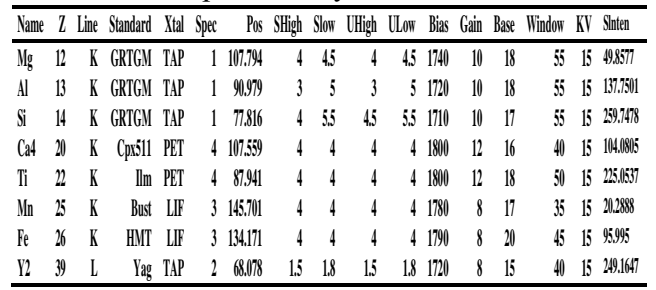



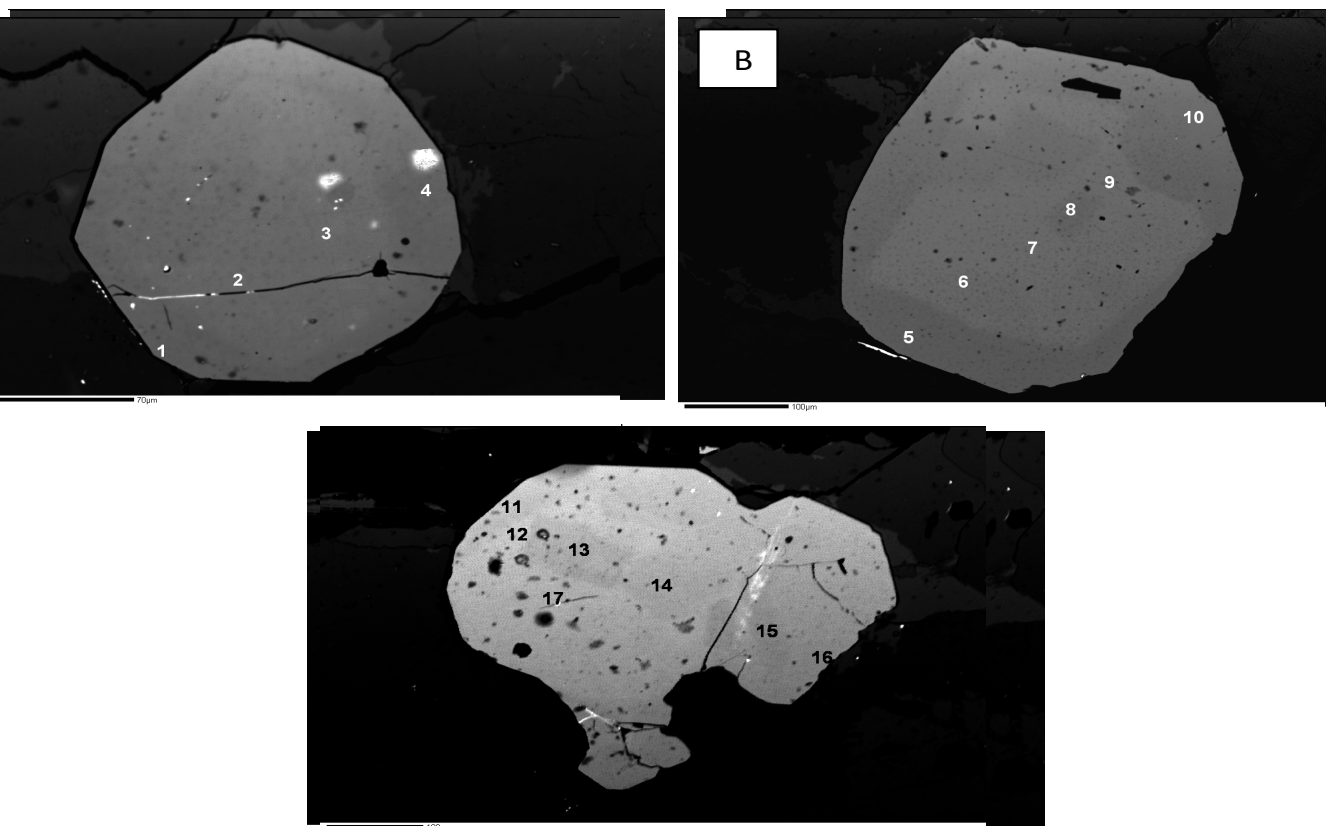

Fig. 24 (A to C): Back-scattered- electron image showing profiles of spots of microprobe analyses in three (3) garnet grains respectively in the peraluminous granites, Um Addebaa area, SED, Egypt

Table 7: Microprobe analysis of three spessartine grains Um Addebaa area, SED, Egypt

\begin{tabular}{llllllllll}
\hline $\mathrm{Pt}$ & $\mathrm{MgO}$ & $\mathrm{Al}_{2} \mathrm{O}_{3}$ & $\mathrm{SiO}_{2}$ & $\mathrm{CaO}$ & $\mathrm{TiO}_{2}$ & $\mathrm{MnO}$ & $\mathrm{FeO}$ & $\mathrm{Y}_{2} \mathrm{O}_{3}$ & Total \\
\hline 1 & $\mathbf{0 . 1 3 4}$ & $\mathbf{2 0 . 1 1}$ & $\mathbf{3 5 . 2 3}$ & $\mathbf{2 . 8 1 3 5}$ & $\mathbf{0 . 0 0 0 9}$ & $\mathbf{1 3 . 9 6}$ & $\mathbf{2 5 . 6 5}$ & $\mathbf{0 . 1 2 8 4}$ & $\mathbf{9 8 . 0 2}$ \\
$\mathbf{2}$ & $\mathbf{0 . 1 7 9 1}$ & $\mathbf{1 9 . 9 9}$ & $\mathbf{3 4 . 6 9}$ & $\mathbf{3 . 5 4}$ & $\mathbf{0 . 0 2 7 3}$ & $\mathbf{1 3 . 2 1}$ & $\mathbf{2 4 . 5 3}$ & $\mathbf{1 . 2 7 2 7}$ & $\mathbf{9 7 . 4 4}$ \\
$\mathbf{3}$ & $\mathbf{0 . 1 7 0 6}$ & $\mathbf{2 0 . 1}$ & $\mathbf{3 4 . 3 6}$ & $\mathbf{3 . 3 1}$ & $\mathbf{0 . 0 3 0 3}$ & $\mathbf{1 3 . 4 7}$ & $\mathbf{2 4 . 9 8}$ & $\mathbf{1 . 2 8 2 8}$ & $\mathbf{9 7 . 7}$ \\
$\mathbf{4}$ & $\mathbf{0 . 1 3 9 9}$ & $\mathbf{2 0 . 2 2}$ & $\mathbf{3 5 . 4 3}$ & $\mathbf{2 . 8 2 3 9}$ & $\mathbf{0}$ & $\mathbf{1 4 . 0 8}$ & $\mathbf{2 5 . 9 6}$ & $\mathbf{0 . 1 3 2 8}$ & $\mathbf{9 8 . 7 9}$ \\
& & & & & & & & & \\
$\mathbf{5}$ & $\mathbf{0 . 1 2 9 7}$ & $\mathbf{2 0 . 3 2}$ & $\mathbf{3 5 . 5}$ & $\mathbf{2 . 7 5 5 8}$ & $\mathbf{0}$ & $\mathbf{1 3 . 6 4}$ & $\mathbf{2 6 . 7 3}$ & $\mathbf{0 . 1 8 1 3}$ & $\mathbf{9 9 . 2 6}$ \\
$\mathbf{6}$ & $\mathbf{0 . 1 3 6 6}$ & $\mathbf{2 0 . 2 3}$ & $\mathbf{3 5 . 0 8}$ & $\mathbf{3 . 3 5}$ & $\mathbf{0 . 0 1 9 7}$ & $\mathbf{1 4 . 9 6}$ & $\mathbf{2 3 . 3 9}$ & $\mathbf{1 . 5 4 9 7}$ & $\mathbf{9 8 . 7 1}$ \\
7 & $\mathbf{0 . 1 2 8 3}$ & $\mathbf{2 0 . 2 4}$ & $\mathbf{3 5 . 0 2}$ & $\mathbf{3 . 4 5}$ & $\mathbf{0 . 2 2 2}$ & $\mathbf{1 5 . 0 9}$ & $\mathbf{2 3 . 2 2}$ & $\mathbf{1 . 6 5 7 3}$ & $\mathbf{9 8 . 8 2}$ \\
$\mathbf{8}$ & $\mathbf{0 . 1 1 2 1}$ & $\mathbf{2 0 . 1 3}$ & $\mathbf{3 5 . 6 7}$ & $\mathbf{4 . 1 7}$ & $\mathbf{0 . 0 1 6 4}$ & $\mathbf{1 4 . 8 1}$ & $\mathbf{2 3 . 8}$ & $\mathbf{0 . 6 7 9 3}$ & $\mathbf{9 9 . 3 8}$ \\
$\mathbf{9}$ & $\mathbf{0 . 1 4 3 6}$ & $\mathbf{2 0 . 1 7}$ & $\mathbf{3 5 . 2 9}$ & $\mathbf{3 . 8 9}$ & $\mathbf{0 . 0 1 2}$ & $\mathbf{1 3 . 9 7}$ & $\mathbf{2 3 . 3 5}$ & $\mathbf{1 . 6 8 6}$ & $\mathbf{9 8 . 5 1}$ \\
10 & $\mathbf{0 . 1 2 4 9}$ & $\mathbf{2 0 . 4 2}$ & $\mathbf{3 6 . 2}$ & $\mathbf{3 . 1 3}$ & $\mathbf{0 . 0 0 4 9}$ & $\mathbf{1 3 . 3 3}$ & $\mathbf{2 6 . 4 7}$ & $\mathbf{0 . 1 8 3 1}$ & $\mathbf{9 9 . 8 6}$ \\
& & & & & & & & & \\
11 & $\mathbf{0 . 1 2 9 3}$ & $\mathbf{2 0 . 4 7}$ & $\mathbf{3 6 . 1 3}$ & $\mathbf{2 . 5 9 3 9}$ & $\mathbf{0 . 0 1 0 5}$ & $\mathbf{1 4 . 3 8}$ & $\mathbf{2 5 . 3 5}$ & $\mathbf{0 . 2 4 0 6}$ & $\mathbf{9 9 . 3}$ \\
12 & $\mathbf{0 . 1 5 9 1}$ & $\mathbf{2 0 . 3 1}$ & $\mathbf{3 5 . 4 1}$ & $\mathbf{3 . 3 2}$ & $\mathbf{0 . 0 1 0 7}$ & $\mathbf{1 3 . 7 5}$ & $\mathbf{2 3 . 7 6}$ & $\mathbf{1 . 5 7 3 5}$ & $\mathbf{9 8 . 3 1}$ \\
13 & $\mathbf{0 . 1 2 7 5}$ & $\mathbf{2 0 . 1 7}$ & $\mathbf{3 5 . 8 4}$ & $\mathbf{3 . 8 8}$ & $\mathbf{0 . 0 2 1 7}$ & $\mathbf{1 4 . 7 1}$ & $\mathbf{2 3 . 5 4}$ & $\mathbf{0 . 6 3 9}$ & $\mathbf{9 8 . 9 2}$ \\
14 & $\mathbf{0 . 1 3 0 2}$ & $\mathbf{2 0 . 2 4}$ & $\mathbf{3 5 . 7 6}$ & $\mathbf{4 . 2 6}$ & $\mathbf{0 . 0 1 5 2}$ & $\mathbf{1 4 . 8}$ & $\mathbf{2 2 . 7 4}$ & $\mathbf{0 . 7 0 7 5}$ & $\mathbf{9 8 . 6 5}$ \\
15 & $\mathbf{0 . 1 0 9 4}$ & $\mathbf{2 0 . 6 1}$ & $\mathbf{3 6 . 3 5}$ & $\mathbf{4 . 3 8}$ & $\mathbf{0 . 0 1 0 7}$ & $\mathbf{1 3 . 9 4}$ & $\mathbf{2 4 . 3 8}$ & $\mathbf{0}$ & $\mathbf{9 9 . 7 8}$ \\
16 & $\mathbf{0 . 1 3 0 8}$ & $\mathbf{2 0 . 5 2}$ & $\mathbf{3 6 . 1 1}$ & $\mathbf{1 . 9 4 6 3}$ & $\mathbf{0}$ & $\mathbf{1 4 . 4 4}$ & $\mathbf{2 6 . 1 8}$ & $\mathbf{0 . 0 6 1 9}$ & $\mathbf{9 9 . 3 9}$ \\
17 & $\mathbf{0 . 1 6 1 9}$ & $\mathbf{2 0 . 3}$ & $\mathbf{3 5 . 2 9}$ & $\mathbf{3 . 4}$ & $\mathbf{0 . 0 2 9 6}$ & $\mathbf{1 3 . 9 9}$ & $\mathbf{2 3 . 4 3}$ & $\mathbf{1 . 8 4 4 3}$ & $\mathbf{9 8 . 4 6}$ \\
\hline
\end{tabular}



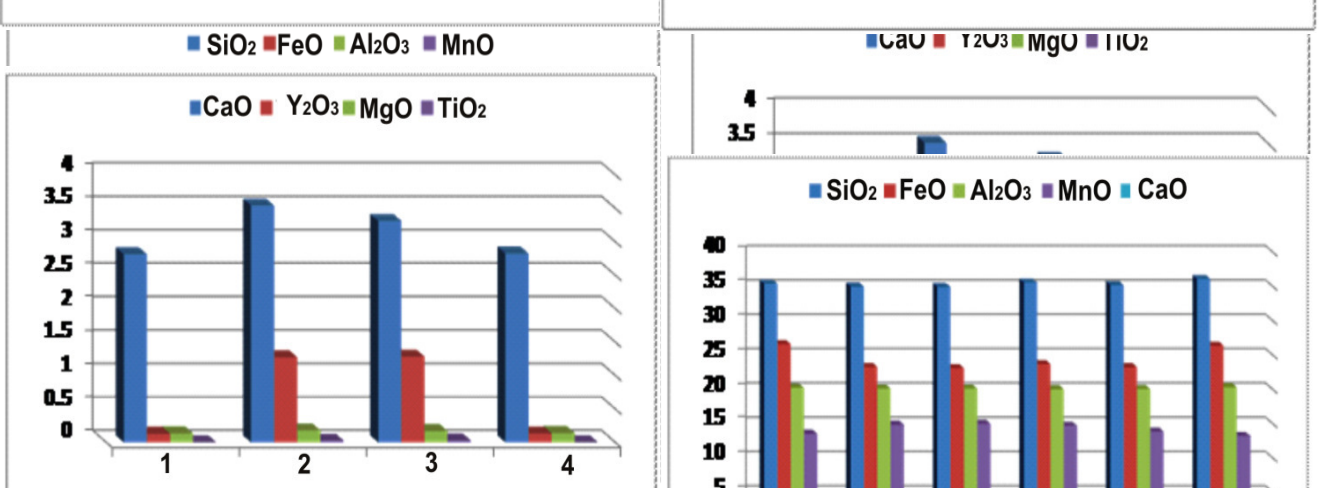

Fig. 25: Bar-diagram of some oxides in spessartine grain no. A
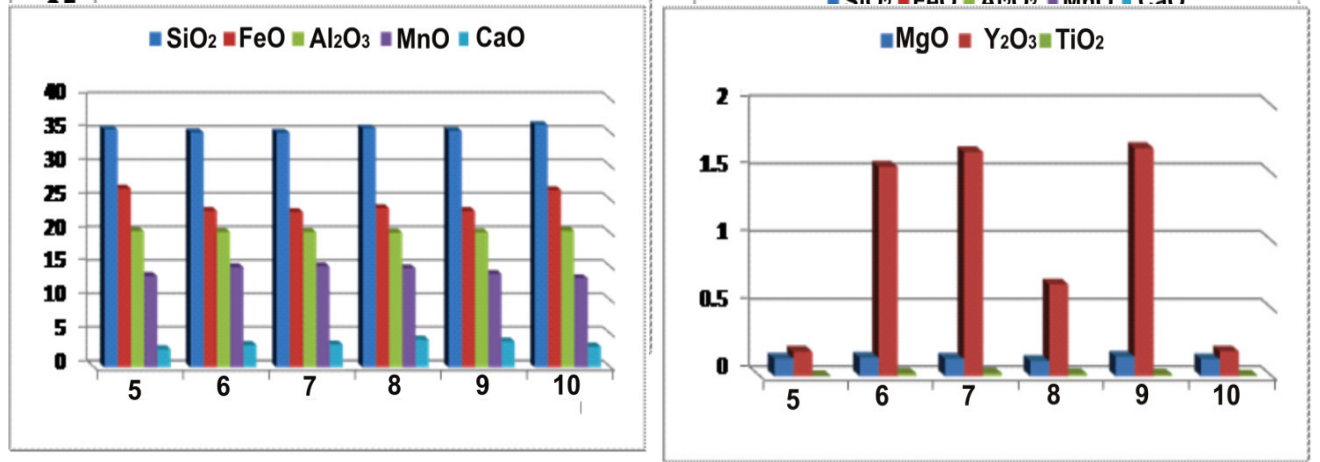

Fig. 26: Bar-diagram of some oxides in spessartine grain no. B
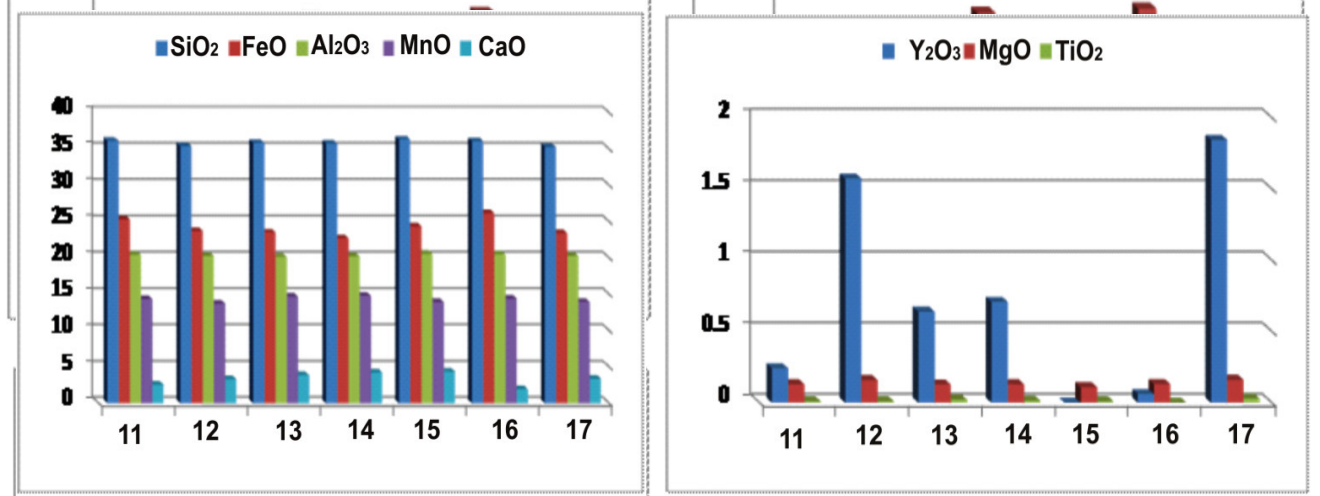

Fig. 27: Bar-diagram of some oxides in spessartine grain no. B 


\section{CONCLUSIONS}

The rocks exposed in Wadi Um Addebaa area include: ophiolitic metagabbro, ophiolitic mélange, peraluminous granite and post granite dykes and veins. The most common feature in the peraluminous granite is the presence of spessartine garnet aligned in monomineralic bands ( $1 \mathrm{~m}$ thick) in parts along the periphery with surrounding schists. The Wadi deposits of W. Um Addebaa (about $2 \mathrm{~km}$ long) contains abundant beryl fractions.

The peraluminous granite is mainly composed of K-feldspar, sodic plagioclase (An 5 -15), quartz, muscovite and biotite. Sericite and chlorite are secondary minerals. Spessartine, tourmaline, zircon, allanite and opaques are accessory minerals. Myrmekitic texture is common indicating metasomatic process.

The presence of muscovite flakes reflects the peraluminous nature of these granites. The presence of two feldspars suggests that the muscovite granites are mostly subsolvus and crystallized under high water pressure.

The deformational features of the studied granite are expressed by bent plagioclase lamellae, distorted microcline twinning, deformed mica flakes, strongly undulatory quartz, development of myrmekite and recrystallization of feldspars into fine-grained aggregates. All these features point to subsolidus. Such deformation should be the result of extensive regional thrusting to which the area had been subjected.

The studied peraluminous granite crystallized from relatively soda rich magma, has peraluminous character, I-type, calc-alkaline affinity and emplaced in syn-collision setting. at relatively shallower depth (water pressure $3-2 \mathrm{~kb}$ ) in the crust and crystallized at temperature range from 800 to $760 \mathrm{C}^{\circ}$.

It possesses high content of LILE ( $\mathrm{Rb}, \mathrm{Y}$ $\& \mathrm{Zr}$ ) and has a moderate to high content of HFSE ( $\mathrm{Cu}, \mathrm{Zn}, \mathrm{Pb}, \mathrm{As}, \mathrm{Bi} \& \mathrm{~W})$.

It possesses an average $6.7 \mathrm{ppm}$ of $\mathrm{Be}$; hence, it is believed that this granite is the source of beryl mineralization in Wadi El Gemal area.

The studied granite has relativelyhigh alkali content $\left(\mathrm{K}_{2} \mathrm{O}+\mathrm{Na}_{2} \mathrm{O}\right)$ and high $\mathrm{Al}_{2} \mathrm{O}_{3}$ contents and relatively low $\mathrm{TiO}_{2}, \mathrm{MgO}, \mathrm{CaO}$, $\mathrm{FeO} \& \mathrm{MnO}$ contents.

Comparing the studied granite relative to the chondrites, it shows a marked enrichment of $\mathrm{Rb}, \mathrm{Th}, \mathrm{K}, \mathrm{La}, \mathrm{Ce}, \mathrm{Nd}, \mathrm{Tb}, \mathrm{Yb}, \mathrm{Sm}, \mathrm{Hf}$ and $\mathrm{Y}$ and depleted in $\mathrm{Ti}$, whereas $\mathrm{Sr}$ and $\mathrm{Ba}$ values around the unity. The studied granitesare characterized by high content of $\mathrm{Cs}, \mathrm{Rb}, \mathrm{U}$, $\mathrm{Tb}, \mathrm{Y}, \mathrm{Yb}$ and moderate enrichment of Ta, Hf, Sm \& K comparing it relative to Bulk continental crust. Otherwise, it has very depletion in $\mathrm{Ba}, \mathrm{Ti} \& \mathrm{Sr}$ while it has moderate depletion of $\mathrm{La}, \mathrm{Ce} \& \mathrm{Nd}$. The strong enrichment content of some elements is due to the presence of some accessory minerals like xenotime, allanite and zircon.

Radiometrically, the studied peraluminous granite shows chemically uranium contents with an average of 19 ppm and thorium contents with an average of $4.5 \mathrm{ppm}$. This also agrees with the spectrometric values that $\mathrm{U}$ content is more than Th content. Uranium content is more than twice Clark value (4 ppm), while eTh content is too less than Clark value (18-20 ppm) suggesting that it is fertile granite. The high $\mathrm{U} / \mathrm{Th}$ ratio of the studied peraluminous granite may be due to their enrichment in radioactive accessory minerals such as zircon.

Some minerals such as beryl and tourmaline are observed by naked eye in the schists of the ophiolitic melange surrounding the peraluminous granite. In the peraluminous granite itself garnet (spessartine) is observed also by naked eye. Other some minerals such as zircon and xenotime are detected by SEM.

From microprobe study, garnet is mainly spessartine with a core rich in $\mathrm{CaO}, \mathrm{MgO}$ and $\mathrm{Y}_{2} \mathrm{O}_{3}$, while the rim is enriched in $\mathrm{FeO}$ and $\mathrm{Al}_{2} \mathrm{O}_{3}$ and $\mathrm{SiO}_{2}$. $\mathrm{MnO}$ shows variable en- 
richment.

\section{Acknowledgements}

The author wishes to express his deep gratitude to Prof. David Lentz (Prof. of economic geology) University of New Brunswick (UNB) for his encouragement and kind help, to Dr. Douglas C. Hall (Microscopy and Microanalysis Facility, University of New Brunswick (UNB), Canada) for kind help during the laboratory work at the laboratories of UNB and to members of Abu Rusheid-Halayeb Project NMA Egypt.

\section{REFERENCES}

Adams, J.A.S., Osmond, Y.K., and Rogers, J.J.W., 1959. The geochemistry of thorium and uranium, Physics and Chemistry of the Earth. Program Press, London, 3, 298-348.

Ashworth, J. R., 1979. Genesis of the Skagit Gneiss migmatites, Washington, and the distinction between possible mechanisms of migmatization: Discussion and reply. Geological Society of America Bulletin, 90, 887-888.

Batchelor, R.A., and Bowden, P., 1985. Petrogenetic interpretation of granitoid rock

series using multi - cationic parameters. Chem. Geol., 48, 43-55.

Barbey, P., Ma Caudiere, J. and Nzent:, J.P., 1990. High-pressure dehydration melting of metapelites: evidence from the migmatites of Yaound (Cameroon). J. Petro., 31, 401- 427.

Boyle, R. W., 1982. Geochemical prospecting for thorium and uranium deposits. Develop. Economic, Geol., 16, El Sevier, Amsterdam, p.489.

Chappell, B.W. and White, A. J. R., 1974. Two contrasting granite types: Pacific Geol., 8, 173174.

Clarke, S. P., Peterman, Z. E., and Heier, K. S., 1966. Abundance of uranium, thorium and potassium, In: S.P. Clarke 4,J (Editor), Handbook of physical contacts, Geol. Soc. Am. Mem. 97 sections $24,521-541$.

Clemens, J.D. and Wall, V.J., 1981. Crystallisation and origin of some paraluminous (S-type) granitic magmas. Canad. Mineral., 19, 111-132.

Debon, F., Le Fort P., Sheppard, S. M. F. and Sonet, J., 1986. The four plutonic belts of the Transhimalaya-Himalaya: a chemical mineralogical isotopic and chronological synthesis along a Tibet-Nepal section. J. Petrol, 27, 219-250.

Deer, W. A., Howie, R. A. and Zussman, J., 1992. An introduction to the rock forming minerals. Longman group limited, England. Second edition.

De La Roche, H.; Leterrier, J.; Grandclaude, P. and Marchal, M., 1980. A classification of volcanic and plutonic rocks using R1 - R2 diagram and major element analyses; Its relationships with current nomenclature. Chem. Geol., 29, 183 -210 .

Fyfe, W.S., 1969. Some thoughts on granitic magmas, In: G. Newall and N. Rast (eds.), Mechanism of Igneous Intrusions. Geol. J. Spec. 2, 201- 216.

Gangloff, A., 1970. Notes somaries la geologie des principaux districts uranoferes studies par la CEA, In: Uranium exploration geology, I.A.E.A., Vienna, 77-105 (IAEA-391-16).

Greenberg, J. K., 1981. Characteristics and origin of Egyptian younger granites. Geol. Soc. America Bull., part I, 92, 224-256.

Greiling, R. O., Kroner, A, El Ramly, M. F. and Rashwan, A, A., 1987. Structural relationships between the southern and central parts of the Eastern Desert of Egypt; Details of a fold and thrust belt. In: El Gaby, Greiling, R. (eds.). The Pan-African belt of NE Africa and adjacent areas- tectonic evolution and economic aspects of a late Proterozoic orogen.Vieweg. Wiesbaden. 121-145.

Gronet, L.P. and Silver, L.T., 1983. Rare earth element distributions among minerals in a granodiorite and their petrogenetic implications. 
Geochim. Cosmochim Acta, 47, 925-939.

Hassan, M., El-Bakry ,H., Al-Amin, and Al Bassiony, Q., 1984. Geochemical orientation survey of tungsten mineralization in arid conditions, eastern desert, Egypt Bul. Fac Sci Zagazig Univ . $6,38-54$.

Hume, W. F., 1934. Geology of Egypt. V. II, Part I. The metamorphic Rocks. Geol. Surv. Egypt. Government Press, Cairo, 300 P.

International Atomic Energy Ageney (IAEA), 1979. Gamma ray surveys in uranium exploration, Technical Report Series, paper no.186, 90p.Vienna.

Ibrahim, M.E., Saleh, G.M. and Abd EL-Naby, H. H., 2001. Uranium mineralization in the two mica granite of Gabal Ribdab area, South Eastern Desert, Egypt. Applied Radiation and Isotopes, 55, 861-872.

Inger, S. and Harris, N., 1993. Geochemical constraints on leucogranite magmatism in the Langtang Valley.Nepal Himalaya.J.Petrol 34, 345-368.

Khaleal, F. M., and Mahmoud, M. A., 2009. Radiometric and mineralogical studies on the muscovite granites at Wadi El Gemal area, Southeastern Desert, Egypt.Sci. J. Fac. Sci. Minufia Univ. XXIII(2), 121-147.

Luth, W. C., Jams, R. H. and Tuttle, O. F., 1964. The granite system at pressure of 4 to 10 kilobars. J. Geophys. Res., 69, 759-773.

Mahmoud, M., 2009. Highlight on the geology, geochemistry and spectrometry of the muscovite granites at Wadi El Gemal area, South Eastern Desert, Egypt, Ph.D. Thesis, Suez Canal University, Egypt, 227p.

Mahood, G. A., Nibler, G. E. and Halliday, A. N., 1996. Zoning patterns and petrologic processes in peraluminous magma chambers: Hall Canyon pluton, Panamint Mountains, California: Geological Society of America Bulletin, 108, 437-453.

Maniar, P.D., and Piccoli, P.M., 1989. Tectonic dis- crimination of granitiods. Geol. Soc. Am. Bull., 101, 635-643.

Middlemost, E.A.K., 1985. Magmas and magmatic rocks. An introduction to igneous petrology. Longmen Group Ltd, Essex, 266p.

Mohamed F. H. and Hassanen M. A., 1997. Geochemistry and petrogenesis of Sikait leucogranite, Egypt: an example of S-type granite in a metapelitic sequence. Geol. Rundsch. 86, 81-92.

Nabelek, P. I., Lin, M. and Sirbescu, M., 2001. Thermo-rheological, shear-heating model for leucogranite generation, metamorphism and deformation during the Proterozoic Trans-Hudson orogeny, Black Hills, South Dakota. Tectonophysics, 342, 371-388.

Omar, S. A., 2001. Characterization and evaluation of some beryl occurrences in the Eastern Desert, Egypt. Ph. D. Thesis, Cairo univ. Egypt, $258 \mathrm{p}$.

Paterson, S.R., Vernon, R. H., Tobisch, O.H., 1989. Preview of criteria for the identification of magmatic and tectonic foliations in granitiods. $\mathrm{J}$. structrual Geol. 11, 340-363.

Pearce, J. A., Harris, N.B.W. and Tindle, A.G., 1984. Trace element discrimination diagrams for the tectonic interpretation of granitic rocks. J. Petrol. 25, 956-983.

Peccerillo, A. and Taylor, S. R., 1976. Geochemistry of Eocene calc-alkaline rocks from the Kastamonu area, northern Turkey. Contr. Min. Petrol., 58, 63-81

Philips, G. N.,Wall,V.J. and Clemens, J.D., 1981. Petrology of the Sorathbogic batholith: A cordierite-bearing granite. Can. Mineral 19, 47-63.

Royden, L. H., 1993. The steady-state thermal structure of eroding orogenic belts and accretionary prisms; J. Geophys. Res., 98. 4, 487-4,507.

Saleh, G. M., 1997. The potentiality of uranium occurrences in Wadi Nugrus area, south Eastern Desert, Egypt. Ph. D. Thesis Mans. Univ. 171 p. 
Saleh, G. M., Abd El Naby, H. H, and Ibrahim, M. E., 2002. Granite magmatism in the Gabal Harhagit area, South Eastern Desert, Egypt: Characteristics and petrogenesis. Egyptian J. of Geology. 46/1, 117-126.

Smith, P. J., 1974. Ophiolites and oceanic lithosphere nature. London 250, 99-100.

Takla, M. A., and Nowier, A, M., 1980. Mineralogy and mineral chemistry of the ultramafic mass of El- Rubshi, E. D., Egypt. Neves Jahrb. Min. Abh., 140/1, 17-28.

Taylor, S. R. \& McClennan, S. M., 1985. The Continental Crust: Its Composition and Evolution.
Blackwell Scientific Publications, Oxford.

Thompson, A. B., 1982. British Tertiary volcanic province. Scott. J. Geol., 18, 49-107.

Thompson, A, B. and Connolly, J. A. D., 1995. Melting of the continental crust: Some thermal and geological constraints on anatexis in contienental collision zones and other tectonic settings. Journal of Geophysical Research 100, 15, 565-79.

Tuttle, O. F. \& Bowen, N. L., 1958. Origin of granite in the light of experimental studies in the system NaAlSi3O8-KA1Si3O8-SiO3-H2O, Geological Society America Memoir, 74, 1- 153.

\section{جيولوجية وجيوكيميائية صخور الجرانيت الفوق ألمنيومي في منطقة وادي أم الضباع ، جنوب

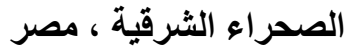

\section{فر اج محمد خليل}

تقع منطقة و ادي أم الضباع علي بعد حو الي • V كم جنوب غرب مدينة مرسي علم. الصخور

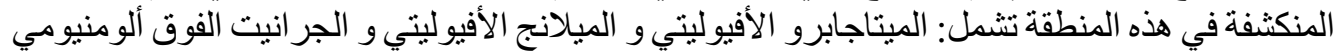

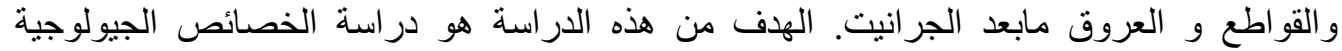

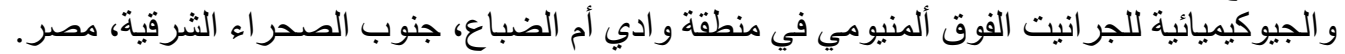

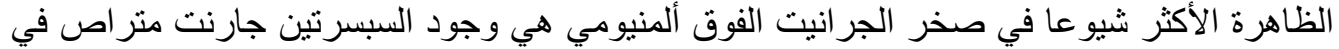

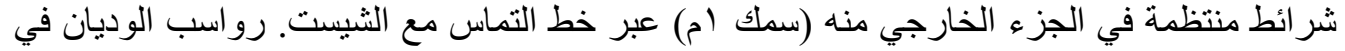

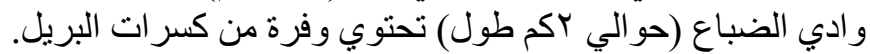

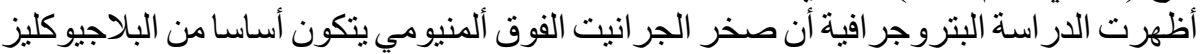

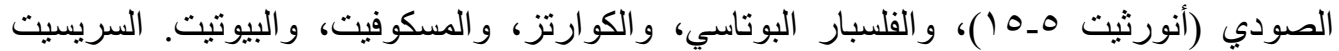

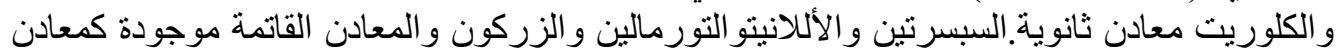

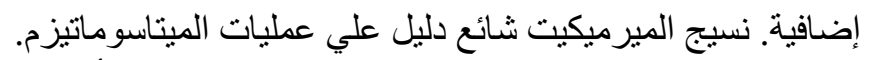

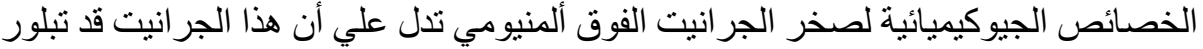

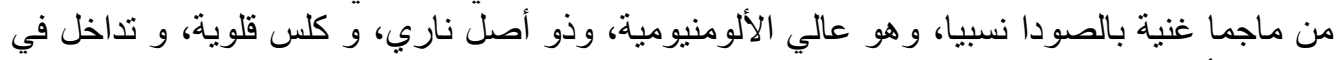

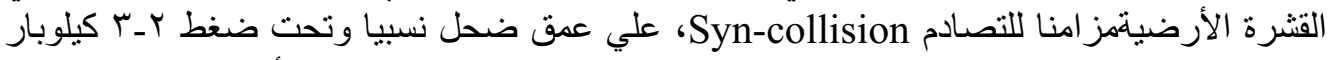

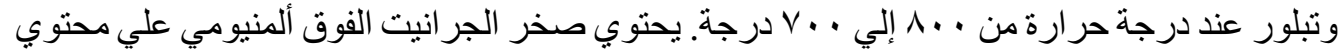

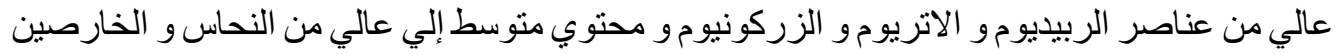

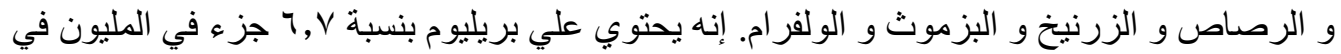

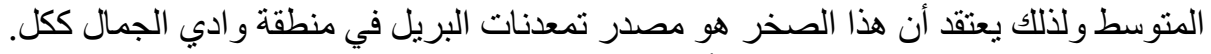

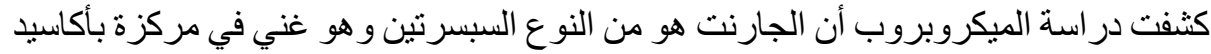


GEOLOGY AND GEOCHEMISTRY OF THE PERALUMINOUS GRANITES 53

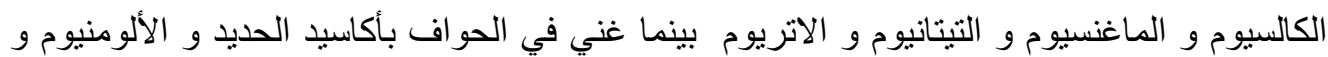

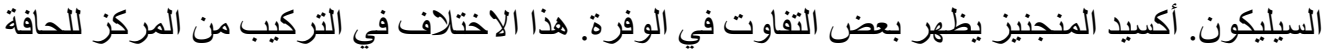
يرجع إلي اختلاف نسبة الحديد و المنجنيز حيث يزداد المنجنيز في المركز أكثر من الحو فاف بينما العكس العن بالنسبة للحديد.

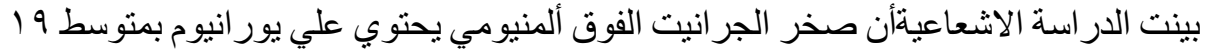

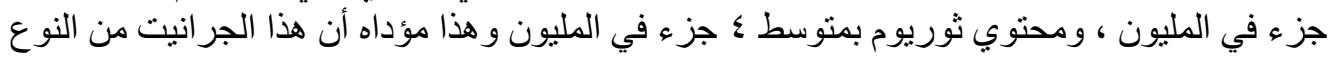
الخصب. 